\title{
The Morphology of Leaf-fall.
}

\author{
BY
}

\author{
E. LEE, A.R.C.SC.
}

Late Marshal Scholar in the Imperial College of Science and Technology, South Kensington; Assistant Lecturer in Botany, Birkbeck College, London.

\section{With Plates IV-VI and twenty Figures in the Text.}

FROM the time of von Mohl's classical paper in I 860 down to the 1 present day, the problem of the physiological and anatomical causes leading to and arising from the natural amputation of the leaf has, with the exception of a short note by Parkin and a passing reference by Woodhead, been exclusively attacked by Continental workers. In the present paper the aspect of the question of the natural amputation of the leaf will be purely anatomical and will relate only to Dicotyledons, and in them exclusively to those species which annually cast off their leaves. A first paper such as this is almost necessarily incomplete, but it is hoped soon to extend the present work to include the examination of other classes of defoliating plants as well as other aspects of this interesting question.

Before passing to a detailed description of the types studied a short summary of the history of the subject will be given, and as the present work is purely anatomical, only a history of observations bearing on that aspect of the subject will now be presented.

As early as the middle of the eighteenth century the phenomenon of leaf-fall had already attracted the serious attention of observers, for in $175^{8} \mathrm{Du}$ Hamel maintained that-

(I) A layer of cells at the base of the petiole always remained herbaceous, and was therefore incapable of supporting the leaf during the winter ; and

(2) After the leaf had ceased to grow in consequence of excessive transpiration, the stem continued to increase in thickness, and this resulted in a tension which ruptured the fibres which unite the leaf to the stem.

Although combated by Mustel (I78I), who showed that there is a plentiful supply of cell-sap in the leaf at the time of leaf-fall, the different points in Du Hamel's theory obtained many supporters, among whom were Murray (1785), Link (1812), and Petit-Thouars (1815). In 1796, however, another view was brought forward by Vrolick, who believed that the imme- 
diate cause of leaf-fall lay in the resorption of cells situated between the dead leaf and the living tissue of the leaf-base and belonging to the latter. $\mathrm{He}$ was generally supported by Vaucher (I82I), Karl Schultz (I 823), de Candolle ( 1827 ), Christian Tréviranus (I 835 ), and in part by Van Tieghem and Guignard (1882). But the great advance was made in 1860 by von Mohl, who, although foreshadowed to a certain extent by Schacht (I 859), showed conclusively that in connexion with leaf-fall two sets of phenomena are brought into operation, viz. those connected with the separation of the leaf from the stem, and those which lead to the protection of the exposed surface. Since the publication of his classical paper on the subject the labours of a long list of observers have resulted in a general confirmation of his results as well as in a great extension of the problem. The extent of our knowledge of leaf-fall phenomena in ferns was well summarized by Paul Bäsecke in I908. The chief workers on Monocotyledonous plants have been F. V. Bretfeld (1879) and Fouilloy (I899), while Parkin (1898) and Woodhead (1906) have each added observations on the occurrence of leaffall in various geophilous species of Monocotyledons. In Dicotyledons, while many investigators have added to our knowledge of the subject, undoubtedly the most important contribution since the time of von Mohl is a paper by Tison (1900) in which are published observations on upwards of eighty species of plants. Much of Tison's work had been confirmed during the present research before his paper became known to the present writer, but a few points of difference will be noted in the separate descriptions of the species. Relying on various small differences, Tison describes no less than eleven special examples, each of which he makes the type of a separate class. Apart from the fact that the creation of so many classes is undesirable as rendering the subject unwieldy, it will be shown later that such a classification is hardly necessary, but also may result in the separation of species which really belong to the same type.

A description of the phenomena as they occur in the different plants studied will now be given. As far as possible common plants will be taken as types, and these will be fully described and will be followed by concise descriptions of plants which naturally fall into the same class. For the bulk of the material and for much assistance I am indebted to $\mathrm{Mr}$. Hales, Curator of the Physic Garden, Chelsea. The rest of the material was obtained through the kindness of Mr. M. Wilson, B.Sc., Mr. L. A. Boodle, F.L.S., and Mr. A. W. Hill, M.A., to whom I beg to express my sincere thanks.

\section{Class I $(a)$. Castanea sativa, Mill.}

As an example of the simple type of leaf-fall, the Sweet Chestnut will now be described. It is to be understood, however, that its position in the scheme is not to be taken as an indication that it represents the first stage 
in the evolution of leaf-fall structures. This may or may not be true, but in any case it is fairly certain that many different lines have been separately evolved.

There is no need to describe the appearance of the leaf of Castanea Suffice it to say that the petiole is slender and roughly cylindrical, and when mature is delimited from the stem by a light brown ring. It is traversed by a group of vascular bundles which in the upper portion divide previous to entering the leaf-blade. In the stem numerous groups of 'stone' cells surround the vascular ring, and as the bundles are given off to supply the leaves, the respective portions of sclerenchyma accompany them. As the leaf-base is approached the lignification becomes less and less pronounced, and the 'stone' cells finally become quite cellulosic; the groups also decrease in bulk, and at the leaf-base almost disappear(Text-fig. I), while the vascular elements also decrease in amount at the transition region. In the upper portion of the petiole the vascular bundles assume their former size, while the strengthening tissue outside the bundles increases in amount and again becomes completely lignified. Thus it is seen that the weakest part of the mature petiole is at the very base where later separation will occur.

By cutting longitudinal sections of the leaf-base, the whole course of events is soon apparent. In point of size there is no difference between the cells of the petiole and the cortical cells of the stem, though the junction is marked by an area of smaller cells. Nor is there any difference in the cell contents : in both cortex and petiole there is a scanty supply of starch granules, and numerous cells contain compound crystals of calcium oxalate. In the mature leaf, however, the layer of smaller cells which separates the cortex from the petiole is evidently very active, as indicated by the great increase in the protoplasmic contents as well as by the manufacture and retention of starch granules. The vascular elements in this region also display the results of increased activity by the presence in the vessels of numerous tyloses (Pl. IV, Fig. 2) and a quantity of a gummy substance which, from its property of taking the lignin stains, has been called by Tison 'gummy lignin'. The tyloses and gummy lignin, acting together, more or less completely obstruct the vessels and so stop the flow of nutrient solutions from the stem.

If a leaf that is just about to fall be examined, it will be seen that the cells on the outer side of the active area at the leaf-base are separating from each other, and the reason is not at once apparent. When, however, a sufficient number of leaves are examined, it is found that the walls of the outer cells of the active area first begin to swell, then become gelatinous, and finally the middle lamellae of a layer of cells in that region become converted into mucilage and dissolve, and the cells gradually separate from each other (P1. IV, Fig. I). During this period of activity the cells of the Separation-layer are distinguished by their abundant protoplasmic contents as well as by a great increase in the number of starch granules present. No 
cell-division has occurred, and the activity assumed by the cells in this region cannot possibly have any connexion with the presence of the stemperiderm, which tapers out and stops at some distance below the area indicated (Text-fig. I, St.pd.). The separation itself usually commences near the dorsal surface of the petiole, and extending rapidly across, soon leaves the leaf adhering solely by the vascular elements. The living cells of the vascular bundles split apart as described, and as soon as the nonliving elements-vessels, \&c.-become ruptured by mechanical means, i. e. the weight of the leaf, wind, \&c., the leaf falls to the ground.

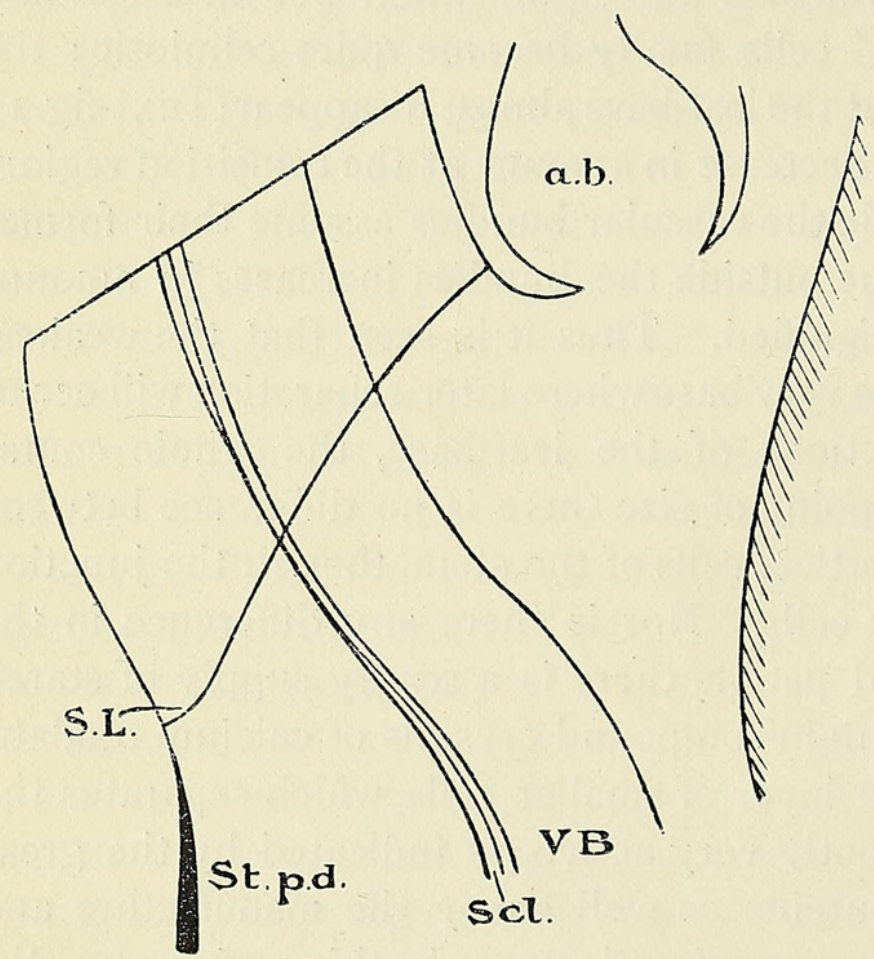

TEXT-FIG. I. Castanea sativa. Longitudinal section of leaf-base at time of leaf-fall.

Beyond the massing of the protoplasm in the cells at the base of the petiole, there has, at this time, been no formation which could be described as protecting the exposed surface. Directly after leaf-fall, however, the activity of the cells below the surface of separation is at once shown by the change in the chemical composition of the cell-walls. Very gradually these become more or less completely lignified. This process commences in regions which vary with the individual specimen, being generally situated near the epidermis, and spreads rapidly until the whole of the Protective-layer has undergone lignification (P1. IV, Fig. 2). At the same time there is deposited on the inner surface of each cell-wall of the Protective-layer a fine film of suberin, the completion of which is marked by the disappearance of the protoplasm from the cells of the area.

Between the area which undergoes ligno-suberization and the exposed surface, there is a layer consisting of 2-3 rows of cells which for a time remains entirely unaffected by the changes going on around it. For a long time these cells retain their protoplasm and their cellulose character, but gradually the protoplasm in the outer cells disappears, and the latter collapse and form a protective membrane. The change thus initiated spreads to the other cells of this layer until finally all the protoplasm disappears and the walls of the collapsed cells, while still remaining more or less cellulosic, become adpressed to the surface and form a very efficient method of protection in addition to the Protective-layer proper (Text-fig. 2, P.S.). 


$$
\text { Lee.-The Morphology of Leaf-fall. }
$$

The layer just described is distinguished by Tison as the 'parenchyme sacrifié', though it would be better perhaps to look upon it as the remains of the Separation-layer. Its premier characteristic-that of retaining for a considerable time its protoplasm and unaltered cell-walls-is possibly due to the production within the separating cells of a small amount of some substance, the effect of which is to overcome the tendency to become lignosuberized ; while the second characteristic of collapsing is probably a result of the exposed position of the layer. The thickness of this layer varies greatly ; in some cases it consists simply of the remnants of the cells which have separated, while in other cases it is much thicker and consists of several layers of cells. At a later stage there is no obvious distinction between this layer and the Protectivelayer, the two having become completely ligno-suberized.

In late autumn or winter when the ligno-suberization of the Protective-layer is nearing completion, and when the same change is rapidly occurring in the living elements of the vascular bundle at that level, another process commences which results in the formation of a periderm beneath the Protective-layer. The living cells adjacent to the latter become active, and commence to divide by walls approximately parallel to the surface of the scar

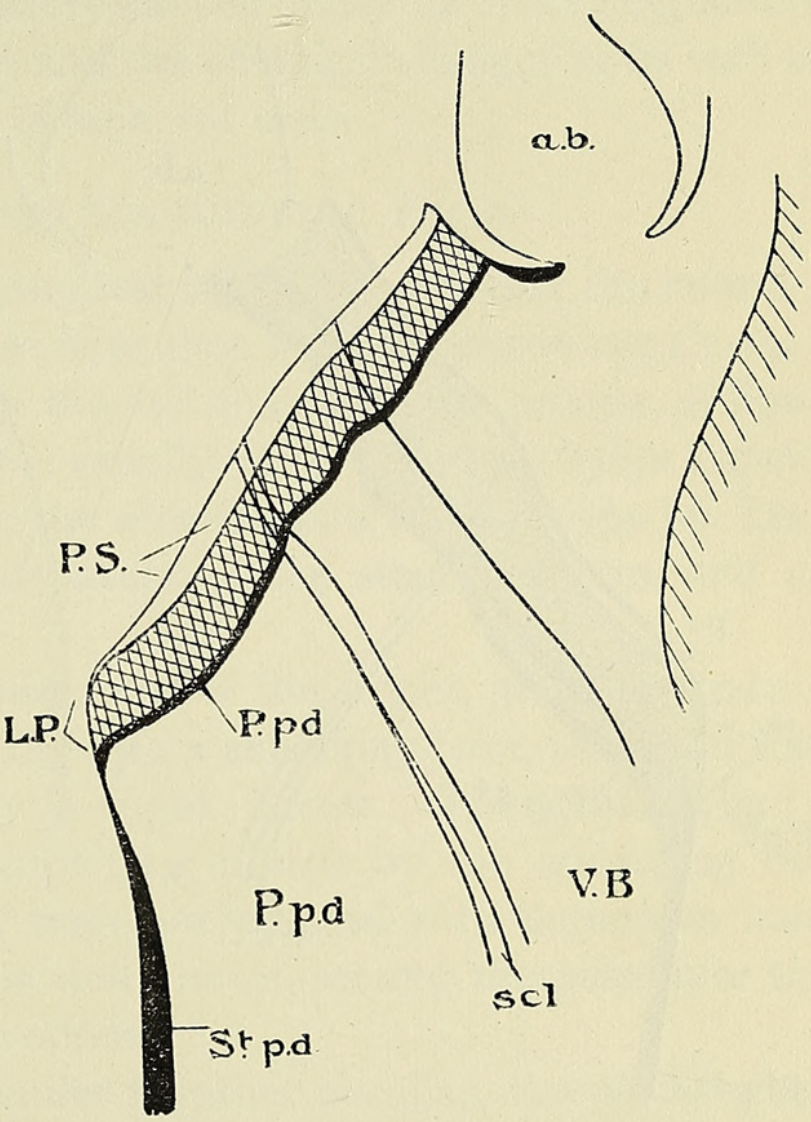

TeXT-FIG. 2. Castanea sativa. Longitudinal section of scar in first winter.

(Pl. IV, Fig. 2, c). In this way a regular cambium is produced, which, starting from the outer epidermis of the leaf-base at some distance above the upper extremity of the stem-periderm, runs across the leaf-base and traversing the vascular bundles joins the inner epidermis just above the junction of the latter with the axillary bud (Text-fig. 2, $P$.pd.). The new cambium becomes continuous across the vascular bundle by division of the living parenchymatous cells of the latter, and when tyloses are present they also divide in the same manner (P1. IV, Fig. $\left.2, t y .{ }^{1}\right)$. The generative layer thus produced differs in no particular from the cork cambium of the stem, and like the latter it cuts off the usual regular cells towards the exterior, and occasionally one or two layers of phelloderm cells towards the cortex. 
While the latter retain their protoplasm and undergo no change, the former become suberized and slightly lignified, and finally entirely lose their contents. Only 3-4 layers of cork cells are produced in the first year.

In the second year, another cambium is produced beneath the leaf-scar and is situated at some distance below the first, and unlike the latter it immediately becomes continuous with the periderm of the stem (Textfig. $\left.3, P . p d \cdot{ }^{1}\right)$. It is approximately parallel with that produced in the first year, but on nearing the vascular bundle it dips down and pursues a curved course within the latter. Four to eight layers are produced before the end

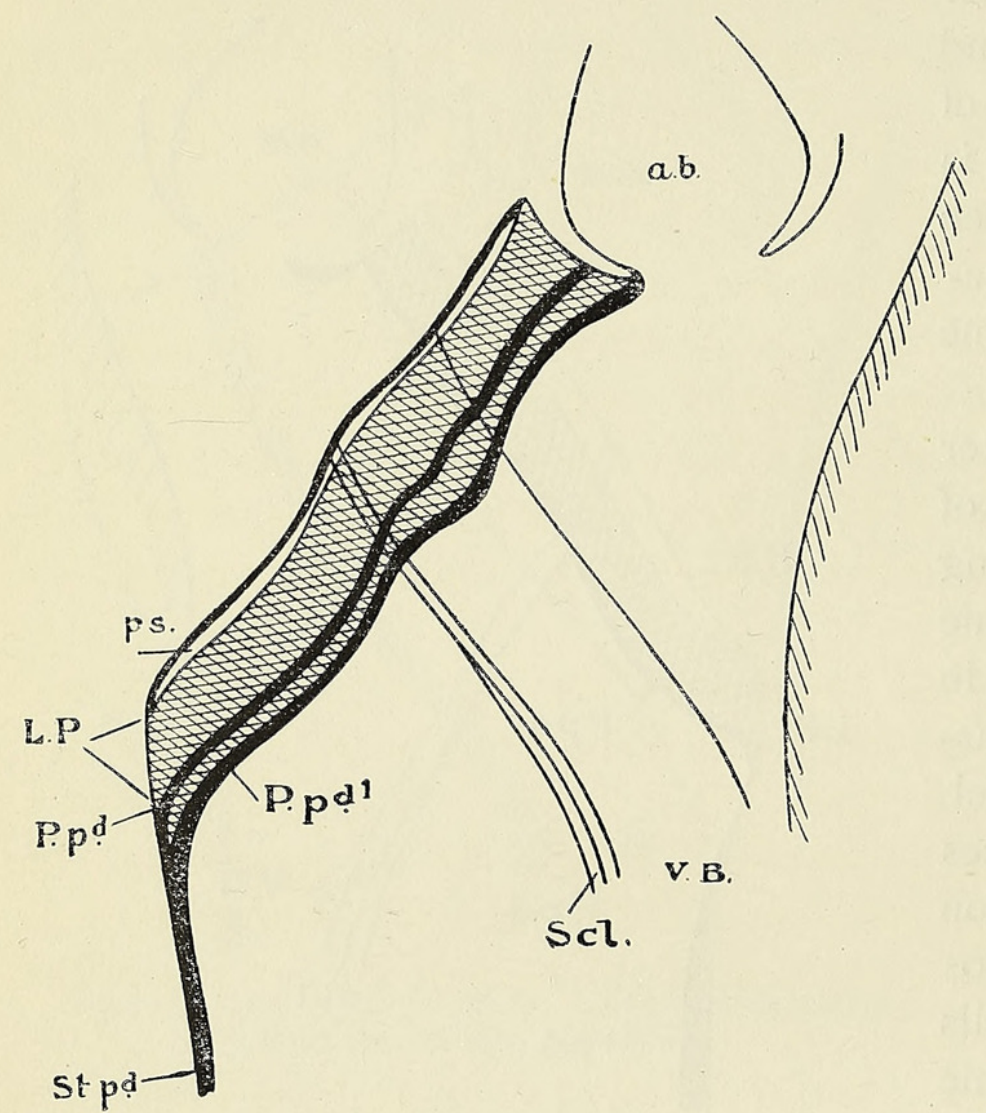

TeXT-FIG. 3. Castanea sativa. Longitudinal section of scar in second winter. of the second year, and at this time all the cells above the periderm have become completely lignosuberized.

Before going on to describe other examples the behaviour of the more peculiar elements present within the Protective-layer may be noticed. It is obvious that the lignified elements of the vascular bundle, such as vessels, strengthening tissues, \&c., from which the protoplasm has finally disappeared long before the complete maturation of the leaf, cannot participate in the further chemical changes which occur in the formation of the Pro-

tective-layer. The sieve tubes, companion cells, and other elements which have retained their living protoplasm undergo the process of ligno-suberization just as do the ordinary parenchymatous cells outside the vascular bundle, and that process is usually not completed until after the formation of the Protective-periderm. Finally there is the behaviour of the crystal cells. When these are included in the Protective-layer the course of events varies with the presence or absence of protoplasm. Sometimes an appreciable amount of protoplasm is present, but more often it is impossible to demonstrate the slightest trace of that substance, and in these cases it appears that the last act of the expiring protoplasm was the secretion of the crystal which now fills its place. It follows then that if protoplasm 
is present it is quite likely that the process of ligno-suberization will be complete, but if absent the cell-wall will but participate in the lignin produced in the surrounding cells ; and this accords with the facts observed. It is quite easy in some cases to demonstrate the inner film of suberin which may even extend round the exterior of the included crystal; but in most cases no such film is to be observed. And the behaviour of the crystal cells when placed in the path of the developing scar cambium leads to the same conclusion; for beyond the conversion of the cellulose wall into suberin with a little lignin there is no further change. If effective protoplasm is present, why should not the crystal cell divide as do its neighbours? But the crystal cell does not divide, and the chemical changes in its wall are probably the result of the activity of adjacent cells.

\section{Class I (b). Ribes sanguineum, Pursh.}

In the example about to be described it will be seen that the course of events is not fundamentally different from that which characterizes Custanea sativa. The chief difference lies in the fact that here the process of lignosuberization of the Protective-layer is usually fairly complete before leaf-fall. Other differences which have led to the erection of a distinct type by Tison are wholly due to the deep-seated nature of the stem-periderm, and are more apparent than real.

In the mature leaf of Ribes sanguineum the upper, green, cylindrical portion of the petiole passes gradually into a sheathing base, the lower limit of which is marked externally by a slight furrow. The axillary bud is large, and its lower portion is completely hidden by the spreading base of the petiole. Both petiole and stem are covered with numerous hairs, which are often glandular and, as is well known, secrete the substance that gives to the plant its characteristic odour.

The distribution of starch granules is rather peculiar, the places where these bodies are found being quite localized, and comprising the cork cambium, phellodcrm, wood parenchyma, and the periphery of the pith. At the time of leaf-fall starch granules are entirely absent from the primary cortex and the Separation-layer, two places where in other species they are almost invariably present. Compound crystals of calcium oxalate are numerous in both cortex and petiole.

Apart from the occurrence of fibres in the vascular ring, stereome is entirely absent from the stem, so that here there is no question of the reduction of the strengthening tissue accompanying the vascular bundles as they enter the leaf. Just below each leaf three bundles leave the ring, and as they traverse the cortex and petiole they gradually converge, finally meeting in the upper part of the petiole and forming a large semicircle. Just above the leaf-base thick-walled sclerenchyma appears outside the phloem of each strand and later forms a continuous cylinder enclosing the 
three vascular bundles. At the same time the hypoderm of the petiole becomes converted into collenchyma, providing an additional source of strength for that organ. Thus again the weakest part of the petiole is its base, when later separation occurs (Text-fig. 4).

As in other examples which will be described later, the Separationlayer (Pl. IV, Fig. 3, S.L.) is well defined long before leaf-fall, its position closely corresponding with the furrow shown externally. It is formed very early by the irregular division of a layer of cells in this region which are distinguished by their dense living and starchy contents, but after once becoming well marked no further change occurs for some time.

As is well known the stem-periderm (Text-fig. 4, St.pd) in Ribes is very deep seated, appearing in the pericycle or endodermis, and this fact exercises a great influence on the

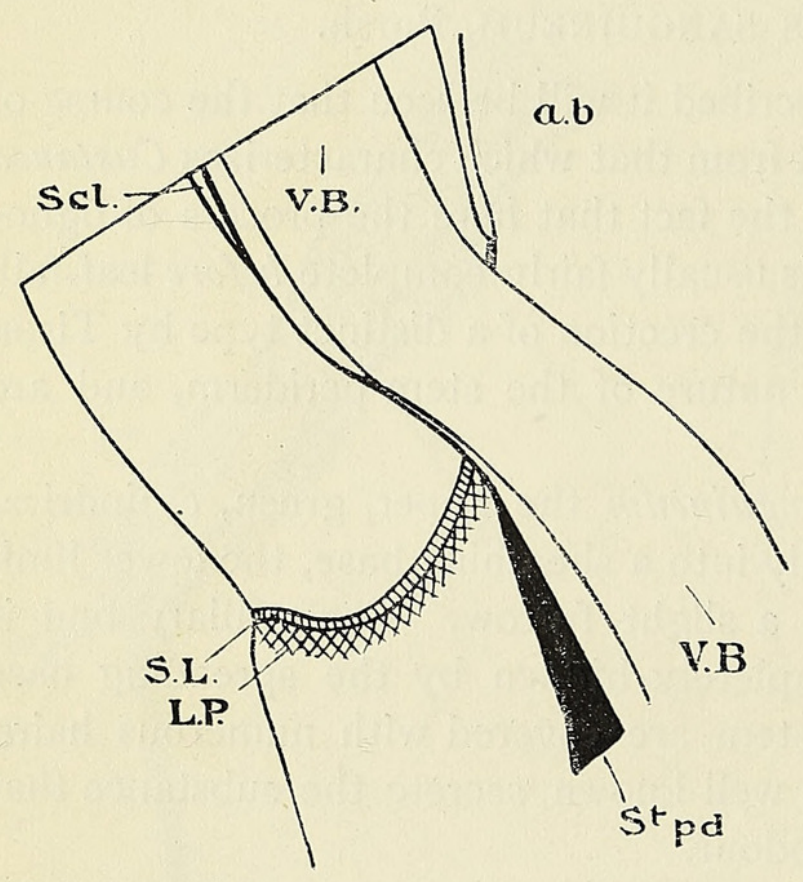

TEXT-FIG. 4. Ribes sanguineum. Longitudinal section of leaf-base just previous to leaf-fall. form and appearance of the modifications connected with leaf-fall. Towards the end of the summer the periderm of the stem attains an appreciable thickness, but as the leaf-base is approached a gradual diminution occurs until finally the periderm ceases, usually at a distance of $2-4$ cells below the Separation-layer. The cortex thus cut off by the periderm becomes crushed, then dies away, and is finally exfoliated. Its behaviour in many respects is markedly different from that of the layer, $2-5$ cells thick, situated just beneath and adjoining the Separation-layer, which, though it undergoes exfoliation along with the general cortex, exhibits modifications which conclusively prove its primarily protective character.

Just before leaf-fall, the cells of the latter layer begin to undergo lignification. This process, which usually commences in a row about five cells away from the Separation-layer, is very definite and gradually spreads across and through the whole layer, more or less completely delimiting it from the ordinary cortical tissue below (Pl. IV, Fig. 3, L.P.). The extent to which lignification occurs before leaf-fall varies greatly, all stages being found from unaltered cells to those completely lignified, and even in very favourable cases partly suberized also. These facts, taken in conjunction with others of a like nature for other examples, point strongly to the conclusion that the degree to which the leaf-fall processes are allowed to occur 


$$
\text { Lee. - The Morphology of Leaf-fall. }
$$

before defoliation is largely if not solely dependent upon the external conditions which usually determine the moment of leaf-fall. When external conditions have not interfered a more or less ligno-suberized layer is present before the separation of the leaf from the stem. The process of lignification takes place as above described, and later a thin film of suberin is added to the inner face of each cell-wall. The only other changes which occur before leaf-fall in the elements at this level are the appearance of a few tyloses and the production of a great amount of gummy lignin in the vessels of the vascular bundles.

Defoliation is accomplished by the splitting apart of the cells of the Separation-layer. The middle lamellae between the cells of the lower two rows begin to swell and are gradually converted into pectic mucilage (which is also impregnated with tannin) and later disappear, leaving the neighbouring cells quite free from each other. About the time of separation there is a great increase in size of the walls of the separating cells, and it seems probable that a differential growth of the separating walls occurs which, if true, will greatly facilitate the process of separation.

In those cases where external conditions have resulted in defoliation before ligno-suberization has been completed, this is rapidly accomplished in the newly-formed scar. By the end of the first year, therefore, the external portion of the scar including the vascular bundle is completely ligno-suberized, but no periderm has been produced which can be said properly to belong to the scar. During the second year, however, divisions occur below the Protective-

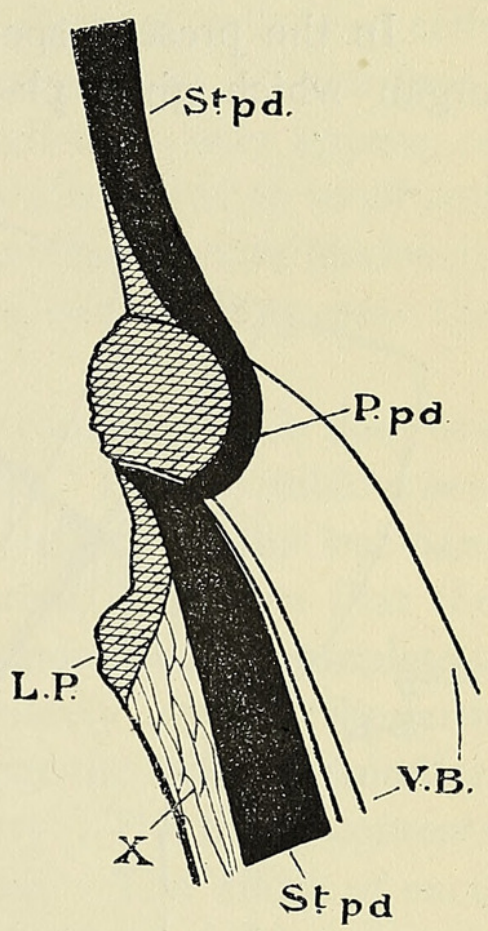

TeXT-FIG. 5. Ribes sangui. neum. Longitudinal section of leaf scar at end of second year. $\mathrm{x}=$ crushed cortex.

layer which result in the production of a definite periderm. A fairly thick layer of cork is produced at the expense of the living cells of both vascular bundle and cortex in this region, and this, starting from the outer portion of the periderm of the axillary branch, traverses the vascular bundle in the form of a basin-shaped curve, which finally ends in the stem-periderm at some distance below its upper extremity (Text-fig. 5, $P . p d$.). Subsequently the vascular tissue above undergoes complete suberization in places where lignification had not previously occurred, the change being very striking even in unstained preparations. 
Class II $(a)$. Tilia Europaea, Linn.

We now enter upon a description of a second type of leaf-fall, taking as our first example the common Lime. The sequence of events is in many respects very similar to that of the examples just described for Class I, but there is one essential difference. Here again, taking the class as a whole, ligno-suberization may or may not occur previous to defoliation; but in every case without exception, new walls running in all directions are produced in the cells of the Protective-layer before ligno-suberization takes place. This is an essential distinction independent of external conditions.

In the present species the petiole is a relatively long, slender, wiry organ which gives place above to the broad lamina, spreading a little towards the base where it

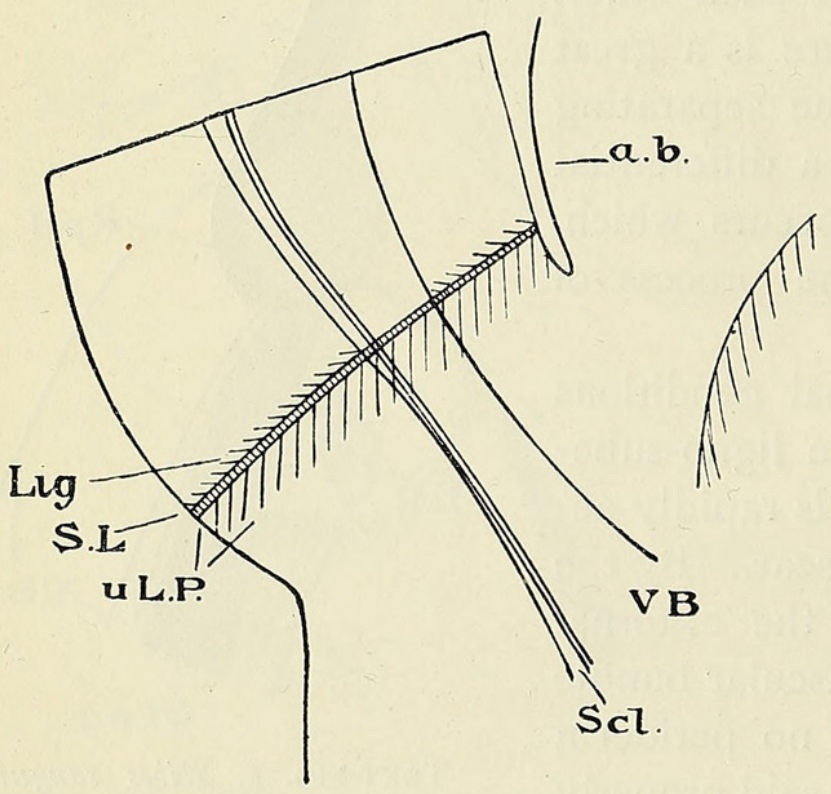

TeXT-FIg. 6. Tilia europaea. Longitudinal section of leaf-base just previous to leaf-fall. curves sharply to join the stem. In the curve is firmly wedged the large asymmetrical axillary bud, which appears slightly to displace the base of the petiole. A slight furrow marks the junction of stem and petiole.

In the upper part of the petiole a conspicuous sheath of stereome surrounds the ring of vascular bundles. As the leaf-base is approached the vascular cylinder gives place to three separate bundles; at the same time there is a gradual reduction in the quantity of sclerenchyma (Text-fig. 6), and the amount of lignification is correspondingly reduced. At the leaf-base itself there is practically no lignification outside the vascular bundles, and the stereome accompanying each has almost disappeared. On joining the vascular ring in the stem the sclerenchymatous patches outside the phloem have again increased to their normal amount and are completely lignified.

There is little or no difference in size between the cells of cortex and petiole, but the junction between the two is marked by a layer of much smaller cells. Early in the season starch granules are present in the cortex, but are entirely absent from the petiole with the exception of the bundle sheath. Simple and compound crystals of calcium oxalate are common to the parenchyma of both organs, and secreting cavities of various size are 
also abundant. Periderm is not present in the stem until long after the leaf has fallen.

As is commonly the case, the increased abundance of the protoplasm in the cells of the leaf-base provides the first indication of approaching leaffall. The small cells of this area become densely filled with brown protoplasm, and starch granules also appear. Considerable activity is displayed, resulting finally in the production of a few new cell-walls, which are scattered (never more than one in each cell) throughout the leaf-base. Beyond the appearance of a few tyloses and a varying quantity of gummy lignin in the vessels of the leaf-trace at this level, no other change occurs in the Protectivelayer previous to defoliation.

Separation in this species is very simple. A layer of cells ( $I-3$ cells thick) just above the Protective-layer becomes conspicuous by the great increase in the starchy contents. A few irregular cell-walls may appear, or these may be entirely absent. The primary cell-walls begin to swell and take the pectic stains more strongly; the middle lamellae become obviously mucilaginous and finally disappear, and separation, commencing near the dorsal surface of the leaf-base, immediately follows.

In Tilia europaea, a further modification is introduced which does not occur in the principal examples previously described. In favourable cases, when the lignin tests are applied to longitudinal sections of the leaf-base taken before the separation of the leaf from the stem, it is seen that the cells above, but adjoining the Separation-layer, are more or less completely lignified. This layer, to which Tison has appropriately applied the term 'Lignified-layer', is usually one cell in thickness near the vascular bundles, but gradually increases to three cells at the periphery. The living contents become reduced in amount and may even disappear. The effect of such lignification is obvious; it gives rigidity to the whole layer, making the adjacent and ever-weakening Separation-layer much weaker by comparison, and thus aiding in the final separation which soon follows (Text-fig. 6, Lig.).

Immediately after the leaf has fallen, the cell-walls of the Protectivelayer begin to undergo lignification followed by a slight amount of suberization. The whole process at this stage is very diffuse and not easily recognized until later, when the Protective-layer becomes delimited below by the production of a regular cork cambium. The crystal cells and secreting cavities which occur in the Protective-layer, but which, of course, have not undergone division like their neighbours, now become highly lignified, but do not display any suberization.

During the first winter the unaltered cells just below the Protectivelayer undergo division by walls approximately parallel to the surface of the scar, and form a cambium which produces a few layers of regular cells towards the Protective-layer. Almost immediately the cells thus cut off become suberized and lose their living contents (Text-fig. $7, P . p d$.). A 
feature of special interest in this connexion is that cells corresponding to the ordinary phelloderm (Pl. IV, Fig. $4, p h$.) are also cut off towards the cortex, and this despite the fact that as yet the stem phellogen has not been produced. It is not, however, until the end of the second season that the periderm becomes continuous across the vascular bundle by division of the living cells of the latter, and about the same time it joins on to the recently formed periderm of the stem (Text-fig. $7, P . p d .{ }^{1}$ ). All the elements above the Protective-periderm have by this time undergone a complete chemical change which, as has been pointed out above, varies with their morphological nature.

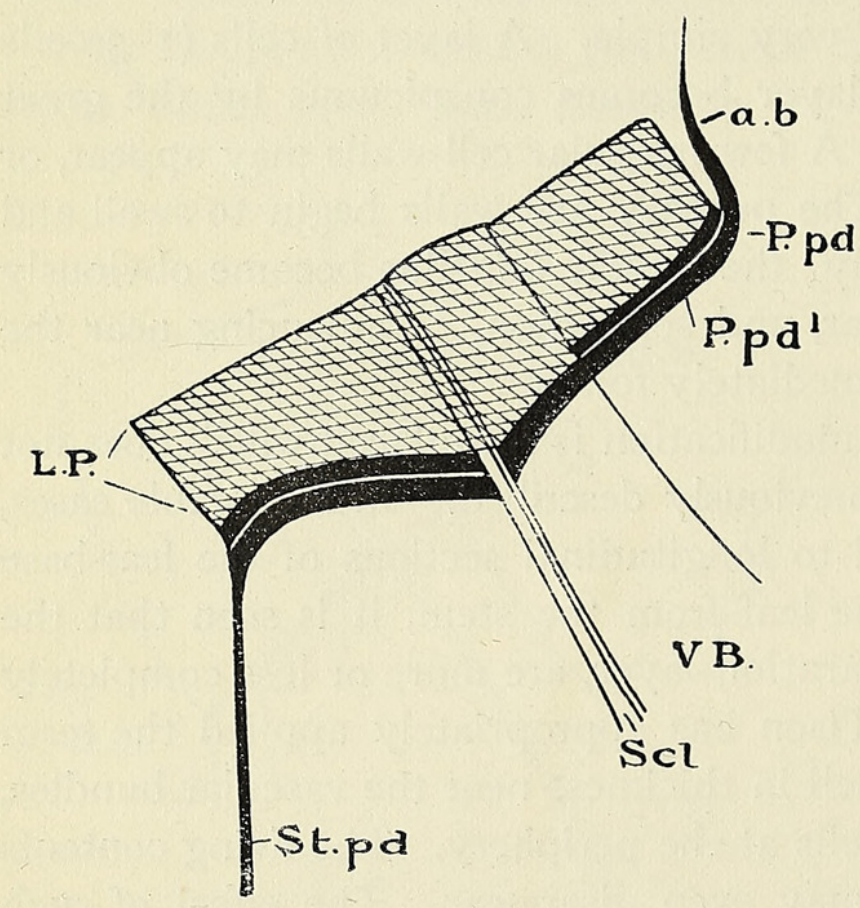

TEXT-FIG. 7. Tilia europaea. Longitudinal section of leaf-scar in second year.

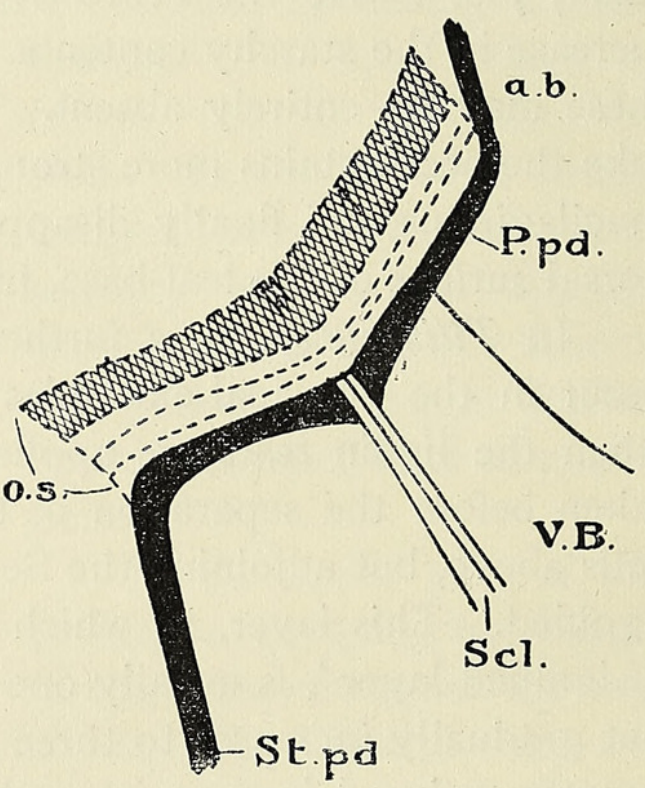

TEXT-FIg. 8. Tilia europaea. Longitudinal section of old scar. o.s. = old part of scar which has been cast off ; $P . p d$. $=$ Protective-periderm of last year.

In the old scars it is of interest to note that the successive cork layers are thrown off, leaving in each case a perfectly plane surface (Text-fig. 8). It will be noticed later that this is a common phenomenon and corresponds to the exfoliation of the successive cork layers in the stem; and one can scarcely avoid the inference that the throwing off in spring of the dead leaf in such cases as Quercus is but the ultimate result of the process, the beginnings of which we see in Tilia.

\section{Class II (b). Betula verrucosa.}

The leaf-fall phenomena in Betula verrucosa are identical in most respects with those which occur in the Lime. There is, however, under ordinary conditions, a difference in the sequence of the chief events, for in 


$$
\text { Lee.-The Morphology of Leaf-fall. }
$$

the present example ligno-suberization of the Protective-layer occurs previous to the amputation of the leaf.

The external morphology of the leaf of Betula, and its relation to the large axillary bud and the stem, are too well known to require description. Internally the arrangements are of the common type. Three vascular bundles leave the ring to supply each leaf, and the patch of sclerenchyma situated outside the phloem of each soon diminishes in amount and finally disappears before the leaf-base is reached. A little way up the petiole it again reappears in its former position, and is assisted in its function by the collenchymatous hypoderm of the petiole.

Starch granules are very numerous in the cortex, but are absent from the mesophyll of the petiole. Compound crystals of calcium oxalate are abundant in both tissues. Periderm is present in the stem long before the commencement of the processes leading to the fall of the leaf.

The first change which occurs in the base of the leaf consists in the increased abundance of the protoplasm of a layer of cells (IO-20 cells in thickness) situated above the junction of cortex and petiole. The layer thus affected is very thick (Text-Fig. 9, L.P.), and its protoplasmic and starchy contents give it an air of activity which is almost immediately justified by the production of numerous cell-walls. These appear singly in each cell, and are

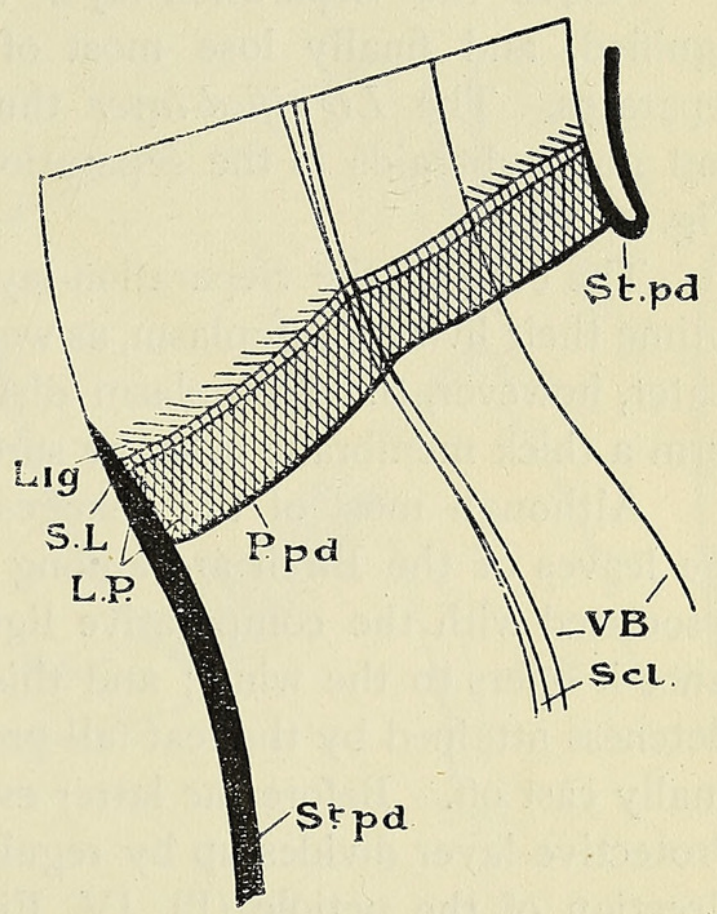

Text-Fig. 9. Betula verrucosa. Longitudinal section of leaf-base just previous to leaf-fall. orientated in all directions. Almost immediately the cell-walls of the Protective-layer begin to undergo change in chemical composition, the process of ligno-suberization commencing near the upper limit of the active area, and spreading downwards until the whole layer is completely changed (Pl. IV, Fig. 5, L.P.). The whole process is quite similar to what has been described for the other examples; the main mass of the wall becomes lignified, while a thin film of suberin appears on the inner face of each cell-wall, with the possible exception of the crystal cells included in the Protective-layer. The protoplasm gradually degenerates and disappears, leaving the ligno-suberized cells quite empty.

Very early in the formation of the Protective-layer, tyloses appear in the vessels of the leaf-trace bundles at that level. They are usually not very numerous, and are chiefly confined to the secondary wood. Gummy 
lignin is produced in great quantity, and fills up the interspaces between the tyloses as well as the vessels from which tyloses are absent.

With the first change in the chemical composition of the Protectivelayer, the adjacent cells above begin to organize into a Separation-layer. This layer (P1. IV, Fig. 5, S.L.), which is 2-6 cells thick, is at once distinguished by the abundance of its living and starchy contents, and by the fact that the chemical changes going on in the walls induce the latter to give a reaction different from that of the surrounding cells. A few irregular division walls may appear, but these are never very extensive. The primary walls begin to swell; the middle lamellae between the outer cells become mucilaginous, and later disappear, and the neighbouring cells separate.

Above the Separation-layer the adjacent cells become completely lignified, and finally lose most of their living contents before the leaf separates. The Lignified-layer thus formed is generally $2-3$ cells thick, and no doubt aids in the separation of the leaf (Text-fig. 9, and P1. IV, Fig. 5, Lig.).

The cells of the Separation-layer which remain on the scar retain for a time their living protoplasm, as well as the cellulose nature of their walls. Later, however, the protoplasm disappears, and the cell-walls collapse and form a thick membrane over the surface of the Protective-layer.

Although most of the changes just described take place quite early, the leaves of the Birch are among the last to fall. Probably this fact is associated with the comparative lightness of the leaf, and the slight resistance it offers to the wind; and this may also explain the degree of completeness attained by the leaf-fall processes in this species before the leaf is finally cast off. Before the latter event occurs, a layer of cells beneath the Protective-layer divides up by regular walls running at right angles to the direction of the petiole (Pl. IV, Fig. 5, ca.). A regular cambium is thus produced, which by division gives rise to a layer of cells towards the Protective-layer. As these are cut off suberization immediately takes place, so that a slight layer of cork is produced before leaf-fall. Subsequently the activity of the cambium increases, and before the end of the first season 4- 6 rows of cork cells have been produced, which, however, are interrupted by the vascular bundles and accompanying stereome (Text-fig. $9, P . p d$.).

In the second year a new cork cambium is produced below the first, and is at once continuous with the periderm of the stem. It curves downwards and traverses the vascular bundles, and by the end of the second year it gives rise to a thick layer of cork.

The examples which have already been described have only one constant difference, i.e. the presence or absence of irregular division walls in the Protective-layer. With this exception the final result is substantially the same. In all these cases the Protective-layer is formed by the metamorphosis of existing cells, and although there is invariably formed beneath 
the scar, by the activity of a cambium, a layer of regular cork cells, this is a formation quite distinct in character and usually bears a definite relation to the periderm of the stem. Its function is to reinforce the already existing Protective-layer, and, later, by becoming continuous with the stemperiderm, to assist in removing the now useless scar structures.

\section{Class III. Salix Caprea, Linn.}

The next class, of which Salix Caprea is the first example, is characterized by the possession of a Protective-layer which is entirely secondary in origin. It is produced by the activity of a single layer of cells which become merismatic, but which for a long time have no possible connexion with the stem-periderm. The whole appearance is quite different from what obtains in other examples even in later stages. But it is upon the morphological distinction that the class is founded.

Taking the Willows as a whole, the external morphology is very similar. The petiole is slender and cylindrical, giving place above to the narrow lamina, and below spreading out where it joins the stem. The sheathing leaf-base, which is provided with a pair of stipular wings, encloses the large dorsally-compressed axillary bud, and a distinct furrow marks its junction with the stem.

Internally, there is no obvious

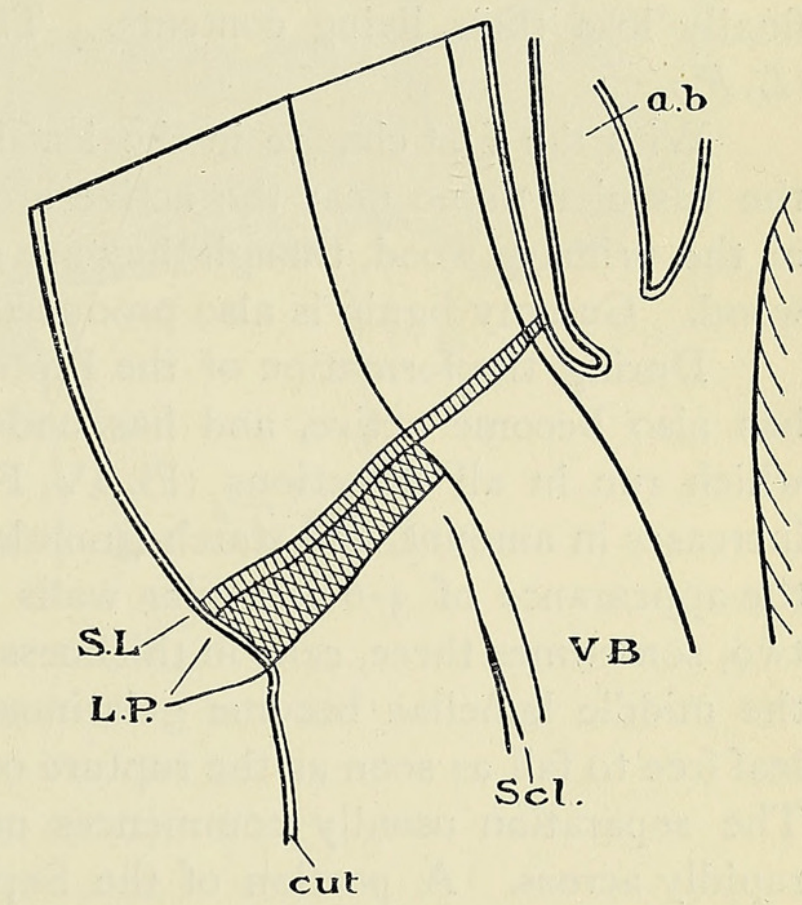

Text-Fig. Io. Salix Caprea. Longitudinal section of leaf-base at the time of leaf-fall. difference in size between the cells of the cortex and those of the petiole. In the former starch granules are abundant, but are absent from the latter with the exception of the bundle sheath. Cortex and petiole alike display fine intercellular space systems, and in both tissues compound crystals of oxalate of lime are abundant. No periderm is present in the stem previous to leaf-fall, but a very conspicuous cuticle protects the surface of both stem and petiole.

On leaving the vascular ring to supply the next leaf, each of the three vascular bundles is accompanied by a patch of sclerenchyma, which, however, disappears before the leaf-base is reached (Text-fig. Io, Scl.). Sclerenchyma is absent from the petiole, but the thick hypoderm is collenchymatous, and no doubt serves to strengthen the petiole.

The absence of periderm in the stem at the time of leaf-fall rids us of 
a complication which in many examples tends to obscure the chief events that precede defoliation. Early in October there is a considerable massing of the protoplasm in the cells of the leaf-base at the level of the furrow shown externally, but, curiously enough, few or no starch granules are to be detected in this area. Very soon regular division walls appear in these active cells, producing a regular cambium which in section has a curved course running across the base of the petiole. By its activity the cambium (Pl. IV, Fig. 6, ca.) gives rise to 6-10 rows of cells towards the petiole and I-2 towards the cortex. The latter (ph.) do not increase very much in size, but retain their cellulose walls and living contents, and are certainly homologous with the phelloderm of the stem; the former, however, become highly suberized with the middle lamellae of lignin, and finally lose their living contents. These constitute the Protective-layer (L.P.).

With the first change in the leaf-base tyloses appear in the vessels of the vascular tissue near the active area, and effectively close the vessels of the primary wood, though they are not very numerous in the secondary wood. Gummy lignin is also produced about the same time.

During the formation of the Protective-layer the adjacent layer above has also become active, and has undergone numerous divisions by walls which run in all directions (PI. IV, Fig. 6, S. L.). The protoplasm first increases in amount, and starch granules are produced; this is followed by the appearance of $3^{-6}$ irregular walls in each cell of this layer, which is two, sometimes three, cells in thickness. The primary walls begin to swell, the middle lamellae become gelatinous and finally disappear, leaving the leaf free to fall as soon as the rupture of the vascular tissue is accomplished. The separation usually commences near the dorsal surface and spreads rapidly across. A portion of the Separation-layer invariably remains on the surface of the scar; the walls of the cells undergo ligno-suberization, their contents disappear, and the collapsed cells form a ragged outer membrane to the scar tissue. No ligno-suberization occurs in the vascular bundles previous to leaf-fall.

It is singular, in view of the elaborate preparations made to bring about defoliation and subsequently to provide adequate protection for the exposed tissue, that in a remarkably small proportion of the leaves yet examined have these modifications been availing. A well-formed Separation-layer is invariably present at the time of leaf-fall, yet-due possibly to the omission of some internal factor, or perhaps to bad climatic conditions which bring about leaf-fall before, so to speak, the leaf is quite ready for itit is often ineffective, and separation takes place by the rupture of the thin lateral walls of the Protective-cambium. There is no evidence of a gradual elongation of the lateral walls such as Tison describes for Aristolochia Sipho, and it is not likely that such occurs, for when gently cutting longi- 


$$
\text { Lee.-The Morphology of Leaf-fall. }
$$

tudinal sections of the leaf-base about the time of leaf-fall, the leaf easily separated along this plane, leaving a clean surface exposed and the underlying tissues quite unprotected.

But whether the Separation-layer is effective or no, the subsequent course of events is the same. In both cases defoliation is followed by the continued activity of the cambium, which produces a few more layers of cells before ceasing for the winter. The ligno-suberization of the new cells does not proceed so quickly or become so complete as in the cells produced previous to leaf-fall, and the last layer formed before the cambium ceases its activity retains its protoplasm and undergoes changes quite different

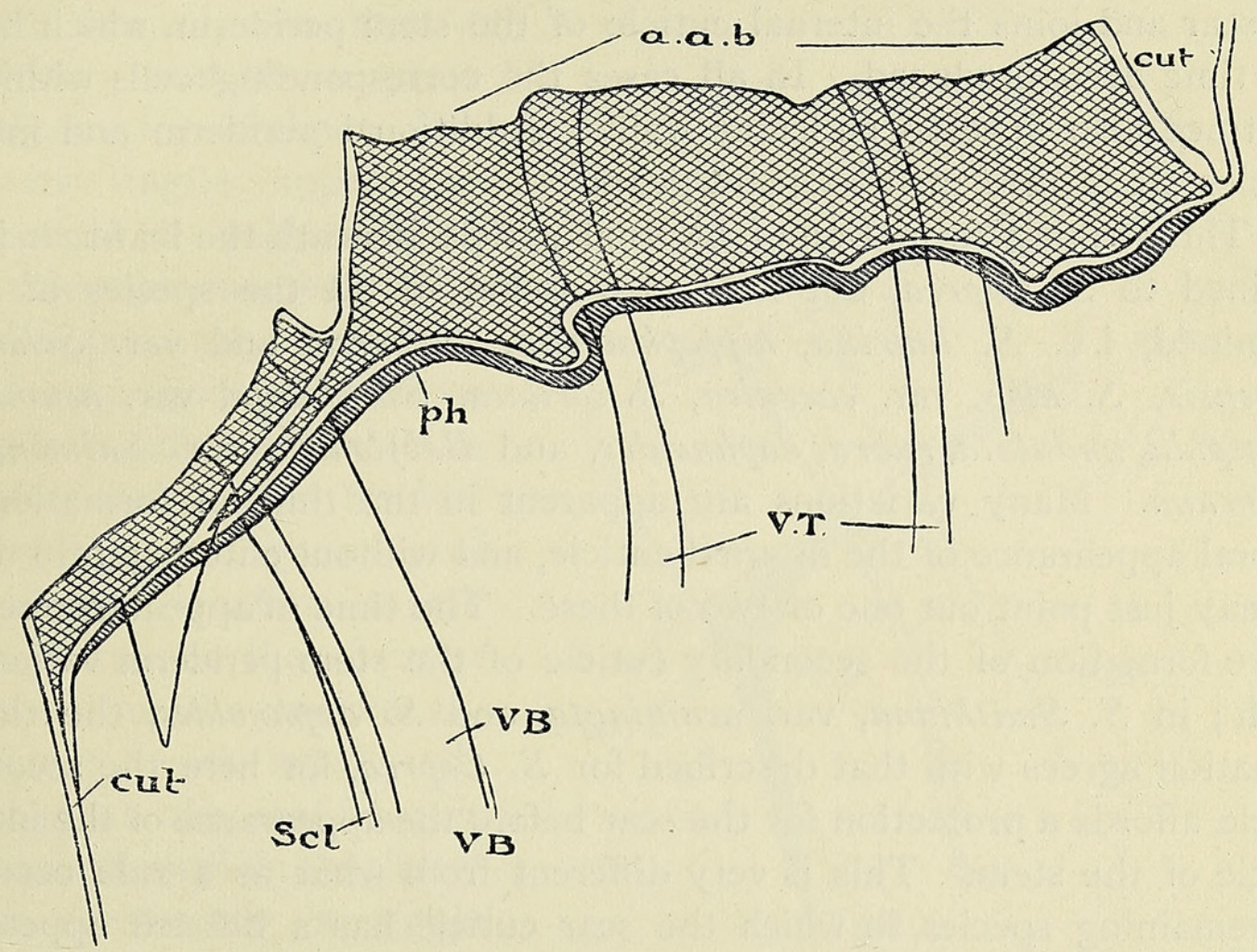

Text-Fig. II. Salix Caprea. Longitudinal section of scar of leaf and axillary bud (a.a.b.), showing distribution of internal cuticle (cut.). V.T. = vascular tissue of aborted axillary bud (a.a.b.).

from those previously described. The cells of this layer remain small and have the usual form of periderm cells; their protoplasmic contents are fairly abundant, but no starch granules are present. Soon the outer wall thickens considerably and gives the reactions for cutin. In some cases the increase in thickness is so great that the lumen of the cell becomes almost obliterated. By the end of January, when this internal cuticle is fully formed, it is very conspicuous, and starting from the stem cuticle at the junction of the petiole and axillary bud, it passes beneath the Protective-layer, and curving downwards, runs parallel with the surface for some distance before finally joining the thick outer cuticle of the stem proper, with which it is chemically identical (Text-fig. I I, and Pl. V, Fig. 7 , cut., cut. ${ }^{1}$ ). 
The living vascular elements above undergo complete chemical change, the wood and bast parenchyma and the companion cells becoming lignosuberized and the sieve tubes submitting to lignification.

During the second year the cambium of the Protective-layer resumes its activity, and usually gives rise to many layers of phelloderm. Sometimes isolated cells in the periderm have been observed to develop a cuticle similar to that just described; and by the end of the second year, a second cuticle, identical with the first and situated a few cells below it, has been produced. This is generally well shown in cases where the axillary bud has become aborted (Text-fig. II). The conditions of the leaf-scar are then reproduced, and the cuticular layer is continued beneath that of the leaf-scar and joins the internal cuticle of the stem periderm, which has by this time been produced. In all cases the corresponding cells within the leaf-trace also develop cuticular walls. Additional periderm and internal cuticles are formed in subsequent years.

This striking formation of internal cuticle beneath the leaf-scar is not confined to $S$. Caprea, but it is also found in all the species of Salix examined, i.e. S. laurina, hippophaefolia, purpurea, and var. Scharfenburgensis, S. alba, var. caerulea, S. cordata, Smithiana, var. acuminata, S. cuspida, undulata, rubra, daphnoides, and Babylonica, var. Salmoni, and S. incana. Many variations are apparent in the time of formation and general appearance of the internal cuticle, and without entering into details we may just point out one or two of these. The time of appearance relative to the formation of the secondary cuticle of the stem periderm varies very much; in S. Smithiana, var. acuminata, and S. daphnoides, the time of formation agrees with that described for $S$. Caprea, for here the secondary cuticle affords a protection for the scar before the appearance of the internal cuticle of the stem. This is very different from what as a rule occurs in the remaining species, in which the scar cuticle has a belated appearance and often seems to be formed as a result of the continuation of the internal cuticle of the stem beneath the scar. It is possibly right to conclude that the degree of dissociation which exists in some species between the formation of the secondary cuticle of the scar and that of the stem is due to the difference in the time of formation of the periderm in the stem, for it is only in cases where the formation of the stem periderm is late that the internal scar cuticle has a separate origin.

Another difference to be noted is the different degree of thickness attained by the internal cuticle. The primary cuticle is invariably thick and conspicuous, and in most cases the internal cuticle is very similar. But in S. incana it is so thin that it can scarcely be recognized even the second year. Correlated with this, the periderm produced beneath the scar in this species is much more abundant than is usually the case. 


\section{Class III $(b)$. Populus balsamifera, Linn.}

It is not surprising, in view of their undoubted affinity, that the course of events connected with leaf-fall should be almost identical in the two genera, Salix and Populus. The species of the latter now to be described was examined because the plant happened to be conveniently situated, and also because the somewhat stouter petiole is more convenient to manipulate. Tison's description of the leaf-fall in $P$. alba almost exactly tallies with what has been observed in the present species.

As is commonly the case in this genus, the petiole of $P$. balsamifera is long and slender, and compressed laterally so that a transverse section appears roughly oval in outline. Despite its fragile appearance the petiole is well supplied with sclerenchyma, especially in the upper part, where it is really very rigid. The three vascular bundles which leave the stem to supply the leaf take with them a quantity of the sclerenchymatous sheath which surrounds the vascular cylinder; but the amount accompanying each rapidly diminishes as the leaf-base is approached until in the latter region often only a single strand remains (Text-fig. I 2 , $S c l$.). The vascular bundles themselves also decrease in bulk as they traverse the leaf-

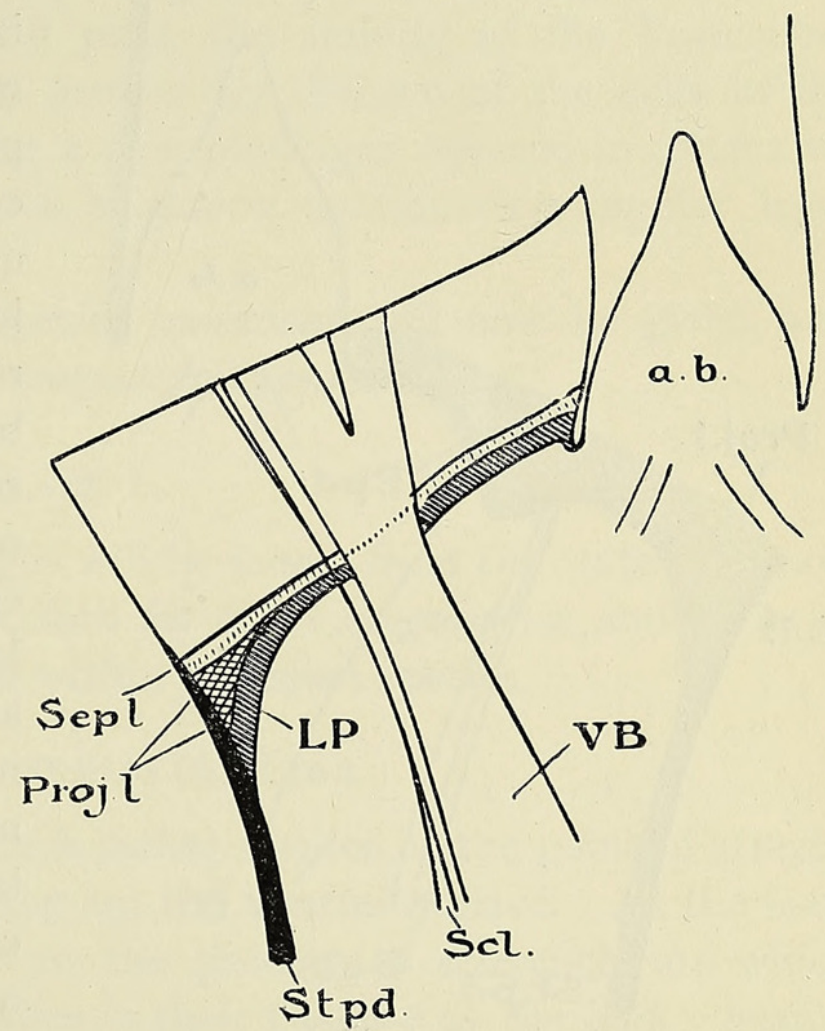

Text-Fig. I2. Populus balsamifera. Longitudinal section of leaf-base at time of leaf-fall. Proj.l.= cells of petiole which occur between Protectivelayer (L.P.) and Separation-layer (Sep. l.).

base, but immediately afterwards each divides several times, and after much interesting orientation three groups of bundles emerge and enter the leafblade. Just above the leaf-base, the single strand of sclerenchyma gives place to a thick sclerenchymatous sheath, which becomes more pronounced the nearer it gets to the lamina.

From the point of view of size, no distinction can be drawn between the cortical cells and those of the petiole. Abundant starch granules are present in the cortex and to a less extent in the petiole, while compound crystals of calcium oxalate are distributed indiscriminately in both. The well-formed hypodermal periderm which is present in the stem extends 
well into the leaf-base, and, as will be seen from the diagrams, is distinct from the Protective-layer formed later (Text-figs. I 2 and I3).

About the end of August or early in September, the protoplasm becomes very abundant in the cells at the junction of cortex and petiole, and the starch granules increase greatly in number. The layer which shows this increased activity consists of $2-3$ rows of cells, and, starting at a point on the inner surface of the petiole just above the junction of the latter with the axillary bud, passes in a slanting direction across the leafbase, and curving downwards joins the stem-periderm at an appreciable distance below its upper limit.

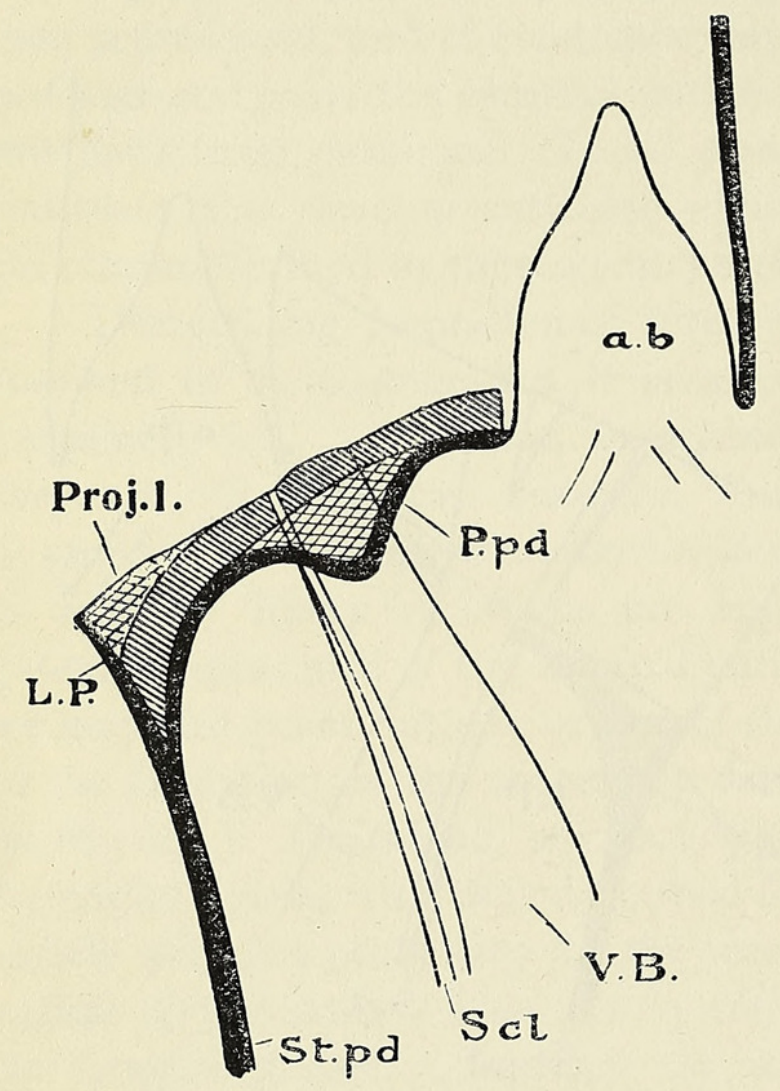

TeXT-FIg. I3. Populus balsamifera. Longitudinal section of two-year-old leaf-scar.

Very soon, division walls appear in the cells of this layer, situated near the dorsal surface, and the process spreads rapidly across, the cells for the most part dividing quite irregularly. The cells of the lower layer, however, divide more regularly and give rise to a cambium which produces $4-8$ rows of cells towards the petiole. As soon as they are cut off, the new cells undergo ligno-suberization, losing in turn their starch granules and living contents, until finally nothing but clear, dead cells remain. The cells of the Protectivelayer possess the form and general characteristics of periderm cork, and although the middle lamellae and corners of the cell-walls exhibit lignification, the main mass consists of suberin. During its activity, the Protective-cambium has become continuous with the phellogen of the stem-periderm, but in spite of this and the general resemblance of the Protective-layer to the cork in the stem, there is really little connexion between the two, the place of junction invariably remaining well marked.

The activity of the cells immediately above the Protective-layer has already been described as having resulted in the formation of more or less irregular walls. These cells still retain their starch and living contents, and division proceeds until walls to the number of $2-5$ have appeared in each cell. The Separation-layer thus formed is early marked off, and, except near the dorsal surface, it is in direct contact with the upper limit of the Protective-layer. Occasionally, however, near the dorsal surface a small 
triangular mass of cells intervenes, and later becomes ligno-suberized and contributes to the bulk of the Protective-layer (Text-figs. I 2 and I3, Proj.l.). The cells of the Separation-layer do not increase very much in size, but the walls of the mother-cells begin to swell, the middle lamellae between the cells of the outer layers gelatinize and finally disappear, and the leaf is freed by the rupture of the vascular bundles. Throughout the whole process the formation of tyloses in the vessels is very scanty, only a few small ingrowths being observed in the vessels of the protoxylem. With the first signs of activity in the leaf-base, however, there is an abundant supply of gummy lignin, which lodges in all the vessels in the region of the Protective-layer, and finally results in the complete blocking of these conducting elements.

About the end of the second year, the activity of the Protectivecambium ceases, and a new one is formed by division of the cells in the cortex beneath. At the same time a new phellogen appears in connexion. with the stem-periderm, and the two becoming continuous a regular layer of periderm is produced.

Short descriptions of other species examined will now be given, and these will be arranged under their respective types.

\section{Class I.}

In the following plants all stages will be found, from the state of events seen in Castanea sativa to that described for Ribes sanguineum, and in many cases all transitions are to be found within the same species.

\section{HIBISCUS SYRIACUS, Linn.}

The slender, cylindrical petiole is rather swollen at the point of attachment, and has a row of hairs running up the ventral surface. At the leafbase there is the usual reduction in the patches of sclerenchyma which accompany the three vascular bundles in their passage to the leaf. Starch granules and compound crystals of calcium oxalate are distributed as usual, and mucilage cavities are also present.

The Separation-layer is formed by the division of $\mathrm{I}-3$ rows of cells, situated at a little distance above the upper extremity of the stem-periderm, and distinguished by their dense protoplasmic and starchy contents. The walls of the uppermost cells swell and become mucilaginous, and separation occurs by the solution of the middle lamellae. No Lignified-layer is present above the Separation-layer. Tyloses and gummy lignin are abundant in the vessels at the leaf-base before separation occurs. Although easily distinguished by reason of the abundance of its cell contents, the Protectivelayer shows no chemical or other change previous to leaf-fall. As soon as the latter has taken place, ligno-suberization, preceded by the disappearance of the starch granules, commences near the exposed surface and spreads rapidly downwards. Lignification is most marked in the lower cells of the 
Protective-layer, and is the only process which occurs in the crystal cells and mucilage cavities.

The cambium which appears below the Protective-layer before the end of the first year is not very active, producing only 2-5 layers of cork cells. In the second year, a new cambium arises at a little distance below the first, and becoming continuous across the vascular bundle, produces a thick layer of cork which is generally curved in a curious manner. An appreciable quantity of phelloderm is also produced.

\section{QUercus Palustris, Muench.}

In this species the cells of the cortex are much smaller than those of the petiole, and are distinguished from the latter by the presence of abundant starch granules. Crystals of calcium oxalate are present in both regions. Groups of peculiar stone cells are found only in the cortex and leaf-base, and the ordinary sclerenchyma which is present outside the phloem of each leaf-trace bundle undergoes great reduction at the leaf-base.

Tyloses appear in the vessels of the leaf-base long before leaf-fall, and are accompanied by the production of a varying amount of gummy lignin. The Protective-layer becomes distinguished by its abundant cell contents, but no other change occurs before leaf-fall. The Separation-layer is produced by division, by approximately parallel walls, of $2-8$ rows of cells, situated a little distance above the junction of the petiole with the axillary bud; and separation occurs in the usual way.

Previous to leaf-fall, division of the cells immediately above the Separation-layer is followed by a process of lignification. After the leaf has fallen, ligno-suberization of the Protective-layer commences near the exposed surface, and spreading downwards completely metamorphoses all the cells at that level, including the living cells of the vascular bundle. The crystal cells become lignified, but the lignified elements of the vascular bundle as well as the patches of stone cells included in the Protective-layer undergo no change.

During the first winter the cambium which arises below the Protectivelayer produces only 4-8 layers of cork cells, and does not establish any connexion with the stem periderm. In the second year the cambium is much more active and produces a thick layer of periderm.

\section{LIGUSTRUM VULGARE, Linn.}

The course of events leading to, and resulting from, the fall of the leaf in the Common Privet is very simple. In the cortex and petiole starch granules are very scanty and other cell contents far from abundant. A single vascular bundle supplies the leaf, and the little sclerenchyma which at first accompanies it entirely disappears at the leaf-base. Little or no 
change occurs in the cells of the Protective-layer previous to leaf-fall. The latter is brought about by the chemical alteration and subsequent disappearance of the middle lamellae of a layer of cells which is never very obvious, and in which no visible preparations occur. After leaf-fall the cells near the exposed surface undergo ligno-suberization, and the cells beneath the Protective-layer divide to form a cambium, which produces a continuous layer of cork in that region.

A fairly well marked Lignified-layer can often be demonstrated before leaf-fall above the Separation-layer. Tyloses are never very numerous, nor is there an abundant formation of gummy lignin.

\section{Celtis occidentalis, Linn.}

In this example there is no essential difference from the method that has already been described for Castanea. Reduction of sclerenchyma and distribution of starch granules and crystals of calcium oxalate are as usual; while in addition groups of 'stone' cells are present in the cortex.

The Separation-layer is formed by the slight division of $\mathbf{I}-2$ rows of cells situated at some distance above the junction of the petiole and axillary bud, and separation occurs by mucilaginization and subsequent disappearance of the middle lamellae. There is no Lignified-layer, and tyloses, though present, are not at all abundant at the time of leaf-fall. Soon after the latter has occurred, ligno-suberization commences in the lower portion of the Protective-layer, and gradually spreads until the whole of the parenchyma in this region-including the living cells of the leaftrace-has become ligno-suberized. The last cells to undergo this change are those near the surface; but later these collapse and become altered in the usual way.

In the first year, the cambium, which arises by division of the cells beneath the Protective-layer, gives rise to I-3 layers of cork and a similar quantity of phelloderm (Pl. V, Fig. 8, co., ph.), the latter being distinguished by the retention of the living protoplasm and cellulose walls and by the presence in many of the cells of a rhomboidal crystal of calcium oxalate (c.c.). The behaviour of these crystal-containing phelloderm cells is very similar to that of many of the stone cells in the cortex which also contain crystals. In both lignification of the cell-wall occurs, and the lignin, instead of being confined to the primary wall, becomes deposited as a film of varying thickness on the surface of the crystal (Pl. V, Fig. 9). This is very noticeable in many of the crystal cells where a connexion exists between the primary cell-wall and the film of lignin which encloses the crystals.

In the second year the activity of the Protective-cambium is continued, and results in the formation of a thick layer of cork and a less quantity of phelloderm. 


\section{PyRus Floribunda, Nichols.}

Externally the junction of the petiole with the stem is marked by a slight groove, while internally little or no difference is apparent, either in the size of the cells or in the cell contents; in both cortex and petiole, starch grains as well as compound crystals of calcium oxalate are uniformly distributed throughout. There is the usual reduction in the sclerenchyma at the leaf-base. Previous to leaf-fall there is no formation of Protective-layer, the only modification being the formation of the Separationlayer in the petiole at a little distance above the junction of the latter with the stem. This is produced by the fairly regular division of $2-3$ rows of cells, distinguished in the usual manner, in each of which I-2 new walls appear. Little or no growth in size occurs ; the primary walls of the outer cells swell considerably, and finally the middle lamellae disappear, and the leaf separates and falls to the ground.

Soon after defoliation, the cells of the Separation-layer which remain on the scar gradually lose their contents and become flattened, forming a well-defined layer which aids in protecting the underlying tissue. The latter also becomes changed and begins to undergo ligno-suberization, the cells finally losing their living contents. At the same time, divisions which take place beneath the Protective-layer give rise to a cambium, which produces a thick layer of cork before the end of the first year.

In the second year the cork cambium continues its activity, and adds considerably to the cork layers. During the whole of the process, few or no tyloses are produced in the vessels of the leaf-trace at the level of the Protective-layer, but the large amount of gummy lignin which appears completely closes these organs.

\section{Ceanothus Gloire-de-Versailles. (Garden origin.)}

The leaf-fall phenomena in this species are very similar to what has been described for Pyrus floribunda, the chief difference being the absence of stem periderm for a long time after leaf-fall. In Ceanothus, also, the position of the Separation-layer is usually fairly high up the petiole, so that an appreciable amount of the latter is left on the stem when the leaf is cast off.

\section{Acer pSeudo-Platanus, Linn.}

In this species the usual characteristics are to be noted, i. e. the presence of starch granuies in the cortex, simple and compound crystals of calcium oxalate in both cortex and petiole, the appearance before leaf-fall of a superficial periderm in the stem, and the complete reduction of lignified sclerenchyma at the leaf-base. 


$$
\text { Lee.-The Morphology of Leaf-fall. }
$$

In the mature leaf the junction of stem and petiole is marked internally by a layer of smaller cells, in which later the protoplasm increases in amount and starch granules appear. The layer of cells thus distinguished runs rather obliquely from near the upper limit of the stem periderm to the junction of the petiole with the axillary bud, and varies in thickness from 6 to 12 cells. No divisions of any kind occur, but the activity of the cells is soon apparent in the changed character of the cell-walls, which now give slight reactions for lignin and suberin. The process of ligno-suberization, which is really very diffuse, probably commences near the upper limit of the Protective-layer, and from thence spreads in all directions; the protoplasm gradually decreases in amount, and the disappearance of the nucleus marks the complete conversion of the cell-wall.

The amputation of the leaf is effected by the separation of the cells adjacent to the Protective-layer on the petiolar side. This layer $(2-3$ cells thick) consists of cells which are rich in protoplasm and starch, and which become divided by a single wall in each case. The new walls invariably remain thin and cellulosic, but the mother-cell walls begin to swell and take the haematoxylin and ruthenium-red with great avidity. The swelling continues and the middle lamellae become entirely mucilaginous and finally disappear, leaving the adjacent cells completely separated.

Some time before leaf-fall a phellogen is formed by the regular division of the cells immediately beneath the Protective-layer, which gives rise before leaf-fall to a layer of 2-6 cells. As the cells are cut off they undergo various changes, but are chiefly distinguished by the fact that they become filled with a dense mixture of mucilage and tannin, just as is the case with the cells cut off by the stem phellogen. This stage may continue for a long time, but sooner or later the mucilaginous mass disappears, and the cells assume the regular appearance and composition of periderm cork.

Little attention has so far been paid to the behaviour of the vascular elements near the affected area. Very early in the course of the changes just described, tyloses appear in the vessels of the primary xylem, and are soon followed by the introduction of a great quantity of gummy lignin. The tyloses are usually far from numerous and seldom appear in the later formed vessels of the leaf-trace. Gummy lignin, however, is invariably abundant, and is found in the majority of the vascular elements situated near the leaf-base. The changes which occur in the parenchyma of the Protective-layer are reproduced in the living elements of the vascular bundle, though the process is usually not completed until after the leaf has fallen. Vascular bundles and patches of sclerenchyma alike provide insuperable obstacles to the continuity of the Protective-periderm formed in the first year, but later formed periderm is interrupted only by the sclerenchyma outside the vascular bundles. 
Ribes Nigrum, Linn.

This species differs from $R$. sanguineum in that: (I) The development of sclerenchyma in the petiole is not so pronounced. In both the rather thick walled cells containing mucilage and tannin which accompany the vascular bundle decrease in number as the latter passes through the Separation-layer. (2) The chief events have a tendency to occur later relatively to the leaf-fall, i.e. ligno-suberization before leaf-fall is much rarer in $R$. nigrum than in $R$. sanguineum.

\section{DiosPyRUS VIRGINIANA, Linn.}

The present species, adopted as a type form by Tison, has therefore been fully described by that author, whose observations have been entirely confirmed in the present research. The petiole is short and erect, and supplied with a single vascular bundle. Sclerenchyma is entirely absent from the petiole with the exception of isolated groups of stone cells. Starch granules and calcium oxalate crystals occur in the cells of both cortex and petiole; periderm may or may not be present in the stem previous to leaf-fall.

The Separation-layer, indicated externally by a furrow, is formed very early by the irregular division of 2-3 rows of cells situated a little distance from the base of the petiole, and as no increase in size occurs this layer is a conspicuous feature. Later the Protective-layer is formed by the lignosuberization, without previous division, of the cells below the Separationlayer. This process commences near the periphery and adjacent to the Separation-layer, and passes like a wave downwards, the protoplasm and starch rapidly disappearing at its approach. About the same time tyloses appear in the larger vessels. No other change occurs until later, when the elements on the periphery of the vascular bundle undergo ligno-suberization, and the protoplasm of the Separation-layer increases in density. The cellwalls of the latter increase a little in thickness, while the cells themselves grow slightly and separate from each other. Apparently there is no production of mucilage, the differential growth of the cells probably accounting for the separation.

At the time of leaf-fall little modification has occurred within the vascular bundle, tyloses and gummy lignin being almost absent. During the second season it is traversed by a cork layer produced by the activity of a cambium; this, however, seldom attains a greater thickness than 3-4 cells.

\section{Halesia tetraptera, Linn.}

Quite similar in most respects to what has been very briefly described above for Diospyrus virginiana is the course of events in Halesia tetraptera. A single vascular bundle invades the petiole. Starch is absent from the 
latter but present in the cortex, while single and cluster crystals of calcium oxalate appear in cells of both tissues and of the leaf-base. A rather deepseated periderm is present in the stem (Pl. V, Fig. 10, st.pd.).

The Protective-layer (L.P.), at first distinguished by reason of its abundant living and starchy contents, becomes distinctly ligno-suberized long before leaf-fall, the process commencing at localized points, from whence it spreads rapidly, soon extending into the vascular bundle. Near the upper and lower boundaries of the Protective-layer the lignin appears to predominate; the walls of the crystal cells undergo lignification only. A few tyloses appear in the larger vessels during the process.

The Separation-layer $(S . L$.$) is formed by the slight division of \mathrm{I}-3$ rows of cells, which as usual are distinguished by possession of much protoplasm and a few starch granules. Separation is effected by the mucilaginization and disappearance of the middle lamellae between the outer layers. No lignification occurs above the Separation-layer.

In the second year a cork cambium arises beneath the Protective-layer, and traversing the vascular bundle, becomes continuous with the stem periderm. As in Diospyrus, a thin layer of cork is the result.

\section{Forsythia Fortunei, Hort. (= F. suspensa, Vahl.).}

The case of $F$. suspensa has been fully dealt with by Tison, who founds a type on the species. To his general description there is little to add, and only a short summary of the course of events will be given. The petiole is short and spreading towards the base, enclosing in its axil the two unequal buds. Neither externally nor internally is there any clear distinction between the petiole and stem except in presence of starch in the cells of the latter. A single vascular bundle supplies each leaf, and in traversing the cortex it loses the whole of the lignified stereome which at first accompanied it.

The slight massing of the protoplasm in the cells of the leaf-base is followed by the more or less complete ligno-suberization of the cell-walls, the latter process commencing in the upper portion, and gradually spreading across and downwards until a fairly thick wedge-shaped Protective-layer has been produced. No previous divisions have occurred in these cells, and at this time few or no tyloses have appeared in the vessels of the leaftrace at this level, although the living elements of the bundle have begun to undergo ligno-suberization.

About this time in the average leaf-base the cells below the Protectivelayer begin to divide regularly and give rise to a cambium which, without traversing the vascular bundle, soon becomes continuous with the wellmarked phellogen of the stem. A few layers of cork may be produced, the number varying with the example and very probably with the position on the branch. 
The Separation-layer is formed, without any division, from the cells of the petiole adjacent to the Protective-layer, and is distinguished in the usual way by its abundant protoplasmic and starchy contents. Later the walls swell slightly, and finally the middle lamellae of the outer cells disappear, and separation results. No lignification occurs in the cells above the Separation-layer. In the second year the cork cambium again becomes active, and taking a more horizontal direction traverses the vascular bundle. Eventually all the cells above become ligno-suberized, and abundant gummy lignin and numerous tyloses appear in the vessels near the leaf-base.

In view of Tison's very clear distinctions between the different types, a case which appeared in this example-instances of which are far from rare in this as well as other species-is especially interesting. On cutting sections of quite ordinary leaf-scars it was found that although there had been the ordinary vital separation, and although the Protective-layer was of the usual shape and well formed, there were no signs either of stem periderm or of Protective-periderm. That is to say, in this case the formation on which Tison bases his type was altogether absent, although apparently everything else was quite normal. Such an occurrence cannot be looked upon as exceptional, for in addition to more than one instance being discovered, all transitions from the normal were found in a very small quantity of material.

\section{BaCCHARIS HALIMIFOLIA, Linn.}

In the mature leaf, the small triangular petiole, which is hollowed out and winged to provide a receptable for the small axillary bud, possesses near its base a deep furrow which marks the position of the Separationlayer. Internally, extensive modifications occur in the three vascular bundles with which the leaf is supplied, for as they traverse the leaf-base, not only are the two patches of sclerenchyma near the xylem and phloem in each reduced to almost nothing, but the bundles themselves decrease considerably in bulk. Another curious feature is the entire absence of starch granules from the cortex and petiole. The junction between the latter is marked by an area of smaller cells in which just before leaf-fall the protoplasm becomes very abundant, and ligno-suberization commences. In the region of the furrow the cells become active, the walls swell and become mucilaginous, and finally separate from each other.

Above the Separation-layer a distinct Lignified-layer is present before leaf-fall. In the fresh scar the exposed cells soon lose their living contents and become flattened out on the surface. Immediately beneath, the process of ligno-suberization, which commenced before defoliation, spreads rapidly (sometimes apparently as two very distinct processes) and extends into the vascular bundles. Later, a cambium arises beneath the Protective-layer and produces from 4 to 8 rows of cork before the end of the second year. 
Gleditschia triacanthos, Linn.

The elucidation of the phenomena connected with the fall of the leaf in this species is rendered excessively difficult by the presence of various structural peculiarities of the leaf-base. As is well known, the latter organ in Gleditschia is much swollen, and hides a cavity which opens to the exterior by a transverse slit on the ventral surface, and in which repose the 3-5 serially-arranged axillary buds (Text-fig. I 4, a.b.s.). Due to some factor-probably the assumption of the fixed light position-growth on one side of the leaf-base is almost invariably greater than on the other, with the result that this part is usually eccentric. Again, the stem-periderm (St.pd.) is rather deep seated and extends up to the narrowest part of the leaf-base ; and the final complication arises from the fact that the quantity of sclerenchyma $(\mathrm{Scl}$.) accompanying the three vascular bundles which supply the leaf is large, and scarcely diminishes in any region.

In addition to the sclerenchyma which surrounds the vascular ring of the stem, numerous groups of stone cells $(S t$.$) are present in the$ cortex, while the parenchymatous cells of the latter often contain simple and compound crystals of calcium oxalate as well as varying

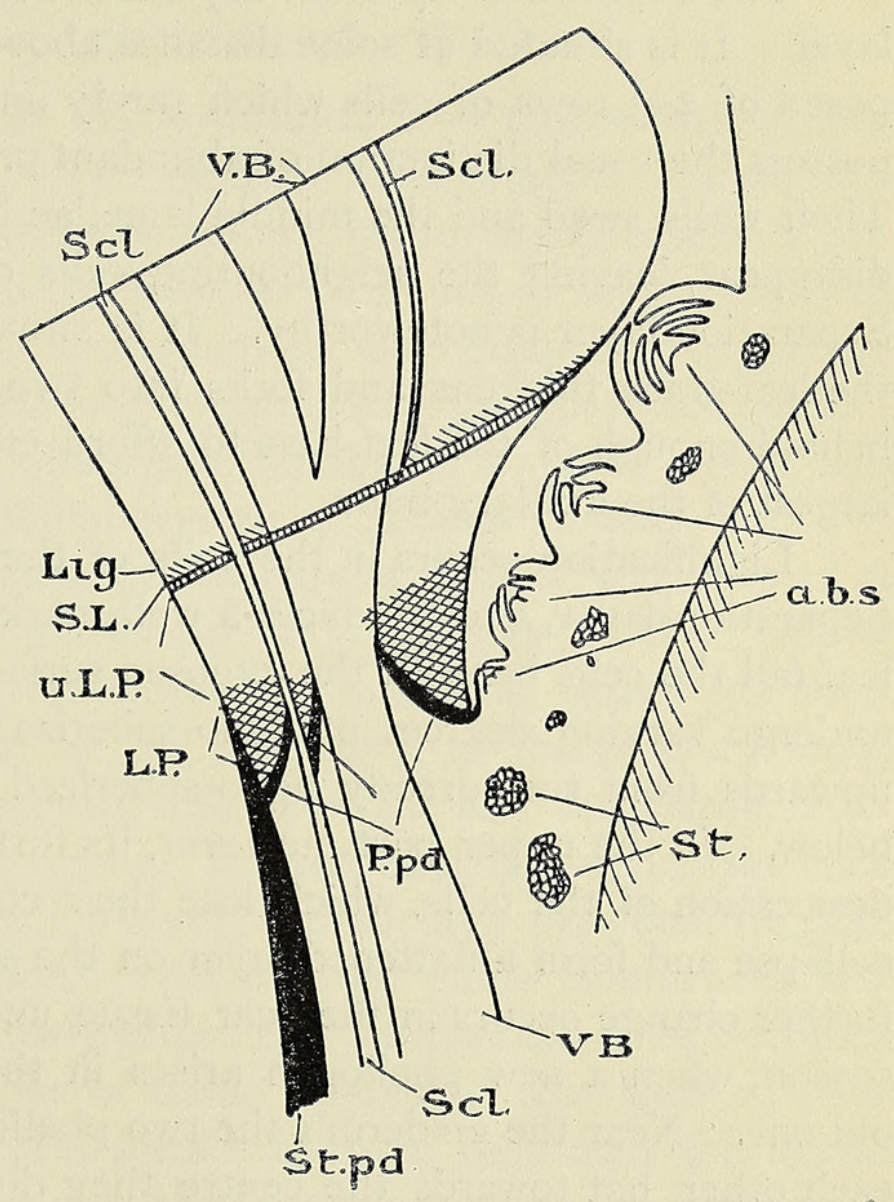

TeXT-FIG. I4. Gleditschia triacanthos. Longitudinal section of leaf-base at time of leaf-fall. quantities of starch.

In the diagram (Text-fig. I4) a median longitudinal section of the leaf-base is shown. There is in this case no conspicuous massing of the protoplasm in the cells at the junction of cortex and petiole. The first indication of the approaching leaf-fall is given by the extension of a branch of the stem periderm in the direction of the vascular bundle, which is interrupted at the phloem of the leaf-trace by the sheath of sclerenchyma $(P . p d$.$) . A similar branch on the opposite side ends in contact with the$ xylem, and all the cells thus produced become only very feebly suberized. 
About this time a few tyloses are developed in the vessels near the leafbase, and a quantity of gummy lignin also appears. A little later the cells just above the periderm begin to undergo lignification, a process which at first is most vigorous in the cells adjacent to the vascular bundle. Suberization first commences near the epidermis, and, though spreading in all directions, it is invariably most conspicuous in the region where it first appears. The Protective-layer (L.P. and $u . L . P$.) thus formed is thin and indefinite above, and consists of cells which have not previously undergone division. The walls of the included crystal cells become lignified only.

The Separation-layer $(S . L$.) has little or no relation to the Protectivelayer. It is situated at some distance above the latter, and is usually composed of 2-3 rows of cells which rarely undergo slight division, and which possess the usual distinction of abundant protoplasmic and starchy contents. Their walls swell and the middle lamellae become mucilaginous and finally disappear, leaving the neighbouring cells quite free. The position of the Separation-layer is noteworthy. It is situated just below the place where the leaf-trace thickens and forks into two, and is so high up as to leave behind enough of the leaf-base to afford efficient protection to all but the largest of the axillary buds.

Lignification occurs in the cells of the petiole immediately above the Separation-layer, and produces a well-marked Lignified-layer (Lig.). After leaf-fall the cells beneath the exposed surface, which are still cellulosic, now undergo varying degrees of ligno-suberization, the latter process spreading upwards from the already ligno-suberized portion of the Protective-layer below. In the upper part, however, its further progress is delayed by the desiccation of the cells, which lose their contents and allow their walls to collapse and form a flattened layer on the surface of the scar. Little or no further change occurs in the scar tissue until the beginning of the second season, when a new phellogen arises in the tissue immediately below the old one. Near the epidermis the two phellogens are almost in contact with each other, but towards the centre they diverge considerably, the primary one rising towards the vascular bundle, the secondary cork cambium dipping down a little towards the leaf-trace, which it completely traverses. A thick layer of regular cork cells is produced before the end of the second season, at which time all the tissue above has undergone complete ligno-suberization.

The scar is triangular in shape, and shows on its surface the three cicatrized nodules representing the three vascular bundles. The uppermost and largest axillary bud alone is visible. 


\section{Robinia Pseudacacia, Linn.}

The leaf-fall and attendant phenomena in $R$. Pseudacacia are quite similar to what has just been described for Gleditschia triacanthos; so that here only the differences will be remarked. The Separation-layer is situated relatively higher in the petiole and so produces a more extensive ' lip', which is thus able to completely enclose all the axillary buds. In its formation, too, there is a difference; it is produced by numerous transverse divisions in a single row of cells, though sometimes it seems probable that more than one row takes part.

\section{Clerodendron trichotomum, Thunb.}

Externally the petiole is hairy and cylindrical, and passes without any clear distinction into the stem. The internal arrangements are slightly different from what may be called the common type, for in this case only two bundles leave the vascular ring in the stem and pass out to supply the leaf, though as usual the sclerenchyma accompanying each disappears before the leaf-base is reached. Starch in the form of granules is present in the cortex; and in the groups of stone cells which are distributed in both cortex and petiole are seen numerous rhomboidal crystals of calcium oxalate.

The Separation-layer is formed by the regular division of $2-3$ rows of cells, and takes a curved course across the leaf-base. It is early defined by the presence of abundant protoplasm and numerous starch granules. Division by $2-4$ walls is followed by the thickening of the primary walls, the middle lamellae of which disappear and allow the leaf to separate from the stem. No Lignified-layer is present. Before defoliation occurs the cells below and adjacent to the Separation-layer, without any previous division, begin to undergo ligno-suberization. This process, which commences near the dorsal surface and spreads slowly across and downwards, never becomes extensive before leaf-fall, the layer of tissue altered at that time varying from one cell thick near the ventral surface to three cells near the dorsal surface. After the leaf has been cast off ligno-suberization proceeds, until at length a fairly thick Protective-layer has become differentiated in this way. Finally the adjacent cells beneath divide up regularly, and so give rise to a cambium which, during the first winter, produces a considerable amount of cork, and which continues its activity during the second season.

Tyloses are never very numerous at any stage of the process, but gummy lignin is invariably abundant in the vessels near the Protectivelayer. In the second year the Protective-cambium becomes continuous across the leaf-trace, all the living elements above it undergoing complete ligno-suberization. The few crystal ('stone') cells which happen to be included in the Protective-layer become lignified only, and often a slight film of lignin is to be detected surrounding the body of the crystal. 


\section{Class II $(a)$.}

\section{Corylus Colurna, Linn.}

Externally the stem and petiole display no special characteristics. Of the internal arrangements it may be noted that the cells of the cortex are smaller than those of the petiole, and are separated by a layer of still smaller cells ; starch granules are abundant in cortex and in the transition layer, but are absent, with the exception of the bundle sheath, from the petiole; cluster crystals of calcium oxalate are numerous in both regions, and a superficial periderm is present in the stem before leaf-fall, while at the leaf-base there is an almost complete reduction in the sclerenchyma accompanying the three vascular bundles which supply the leaf.

The irregular division of the cells at the junction of petiole and cortex by walls which appear singly in each cell and which run in all directions, is preceded by a marked increase in the living contents of these cells, so that although no ligno-suberization occurs previous to leaf-fall, the Protectivelayer is easily recognized.

The Separation-layer, which now appears, is formed by the division of I-3 layers of cells situated above the Protective-layer, and is at once distinguished by abundant living and starchy contents, and by its reactions with stains. Separation occurs in the usual way by mucilaginization and subsequent disappearance of the middle lamella. Throughout the whole process a few tyloses are present, and later gummy lignin is very abundant in the vessels at the leaf-base. A slight Lignified-layer is present above the plane of separation.

Ligno-suberization of the Protective-layer occurs after leaf-fall. The double process takes place in the upper portion, the cells below remaining for a time almost wholly lignified. The chemical alteration of the included crystals and vascular elements takes place in the usual way.

Scar periderm arises about the end of the second season. It traverses the vascular bundles (in which it has a curved course) and becomes continuous with the stem periderm on both sides. In later seasons new periderms arise beneath the first one.

\section{Cercis Siliquastrum, Linn.}

The petiole is slender, and a slight groove at its junction with the stem indicates the position of the Separation-layer. Three bundles supply each leaf, and the usual reduction in the accompanying sclerenchyma occurs at the leaf-base. The first indication of approaching leaf-fall is the regular division of a layer, 2-4 cells in thickness, which runs in an oblique direction just above the leaf-base. New walls appear in these cells quite suddenly, the only previous indication being the slight massing of the protoplasm in this layer. The plane along which the divisions occur is quite definite and 
invariable. It commences near the ventral surface of the petiole just above a small ridge on the inner surface of the petiole, and runs across obliquely to a point very near the upper limit of periderm formation in the stem. The separation which soon follows commences near the ventral surface of the petiole. As the division of the cells (and consequently, their separation) is more and more backward the nearer we approach the dorsal surface, it usually happens that the separation in the latter region is more or less mechanical, and is due to the whole weight of the leaf being thrown on this small area. Although it seems highly probable that the middle lamellae between the separating cells become changed in some way or other to lessen the resistance to separation, no such change could be traced, the tests for mucilage especially giving no positive results. From a comparison of the cell-walls of the Separation-layer before and after separation it seems possible that the disunion is accomplished by differential growth of the respective cell-walls.

At the time of separation there is usually no ligno-suberization of the cells beneath the exposed surface, although a varying number of new cellwalls have appeared. Soon after the cells immediately below begin to undergo change, the process spreading in all directions until a fairly thick layer, including the living tissue within the vascular bundle at that level, has become ligno-suberized. Tyloses appear in some of the larger vessels, and the gummy lignin produced is fairly abundant. Towards the end of the first winter a cambium arises beneath the Protective-layer which in the first year produces a considerable quantity of cork, and which continues its activity in the second year.

\section{Carpinus Betulus, Linn.}

The ordinary characters of stem and petiole (both external and internal) are present in this species. In the processes which take place before and after leaf-fall there is little to distinguish it from any of the other examples of this type. Previous to leaf-fall the cells at the base of the petiole undergo irregular division, but no ligno-suberization occurs until after the leaf has fallen. The Separation-layer, which is usually a fair distance above the junction of the stem and petiole, is formed by more or less irregular divisions in a layer of cells $2-3$ rows in thickness, and separation occurs between the outer cells of this layer. A well-marked Lignifiedlayer is almost invariably present above the Separation-layer. After leaffall, ligno-suberization commences in the cells of the Protective-layer, but is very diffuse, although apparently aided by the distribution of gummy lignin from the vessels. In late winter divisions in the cells beneath the Protectivelayer result in the formation of a cambium, which, however, is not very active.

It is well known that in this species the leaves often remain on the tree during the winter, and it is interesting to see what happens in such 
cases. It is found that the usual processes occur, leading to formation of Protective-layer, and that even the Separation-layer may be partially formed. That is to say, an incomplete Separation-layer is produced which possesses the usual characteristics, but not being continuous it is powerless to effect the separation of the leaf, which therefore remains on the tree. In late winter divisions which occur beneath the Protective-layer result in the formation of a second Separation-layer by the agency of which in the following spring the leaf is thrown off. Tison, who has worked out the formation in some detail, states that the divisions beneath the Protective-layer lead to the formation of a cambium which gives rise to many layers of cork towards the scar. The first layer to be formed, however, retains its cellulose character, the side walls elongate and finally rupture, and the leaf separates from the stem. In the cases examined during the present research the complete course of events has not been ascertained due to failure of material. It appears, however, that little or no cork is formed previous to the throwing off of the dead leaf, and that the elongation of the cell-walls of the Separation-layer is not very great.

\section{Prunus Cerasus, Linn.}

The external morphology of the petiole and adjacent parts is well known, and calls for no special remarks. It might be noted, however, that a fairly deep furrow marks the transition from stem to petiole, and provides a line of weakness which, quite apart from the fact that the plane of the Separation-layer is later coincident with it, is easily recognized by the ease with which the leaf when submitted to pressure breaks at that place.

We have here again to notice the reduction that occurs in the sclerenchyma accompanying the three leaf-trace bundles. When they first leave the vascular cylinder in the stem each is provided with a conspicuous mass of lignified stereome situated outside the phloem, but this entirely disappears just below the leaf-base, and does not again reappear. Higher up the petiole the strengthening tissue consists of collenchymatous hypoderm, and patches of thick-walled cellulose cells which accompany the phloem; but little or none is present at the leaf-base. In a median longitudinal section the vascular bundle is prominent, and the furrow before mentioned is very well marked on the ventral surface of the petiole. There is practically no difference in size between the cells of the cortex and those of the petiole, but the transition region is marked by an area of smaller cells. Starch is present in the cortex, less abundant in the leaf-base, and entirely absent from the petiole, while compound crystals of calcium oxalate are common in all these regions. A hypodermal periderm is present before leaf-fall.

The first stage in the leaf-fall processes is shown by the increased abundance of the protoplasm in the smaller cells of the leaf-base, which almost immediately begin to divide by irregular walls which appear singly 


$$
\text { Lee.-The Morphology of Leaf-fall. }
$$

in each cell. Little growth in size occurs in this Protective-layer, but the cells near the dorsal surface (where the layer is thicker) begin to undergo a chemical change, the process of lignification commencing in this region and extending across the leaf-base to the vascular bundle. Little or no suberization occurs previous to defoliation.

During the processes just described a varying number of tyloses appear in the vessels of the leaf-trace near the active area, and are accompanied by an abundant supply of gummy lignin, together very efficiently closing the lignified conducting elements.

The Separation-layer also arises about the same time. It traverses the petiole in the plane of the external furrow and is produced by the repeated division by $(2-6)$ parallel walls of $2-3$ rows of cells above and adjacent to the Protective-layer. There is an abundance of living and starchy contents in these cells; their walls begin to swell, and the middle lamellae between the outer cells degenerate into pectic mucilage and finally disappear, leaving the neighbouring cells quite free.

Before the final separation occurs, the cells immediately above the Separation-layer, after undergoing one or two divisions, become more or less completely lignified. This layer, which always retains a certain amount of protoplasm, is thickest at the sides and gradually decreases as the centre is approached.

As separation takes place between the upper rows of the Separationlayer there is invariably a mass of unaltered cells left attached to the Protective-layer, which for the most part, until properly exposed, retain their contents and cellulose walls. After complete separation, however, these cells soon lose their turgidity, and dying away, they collapse and become firmly pressed to the surface of the Protective-layer.

In $P$. Cerasus little or no suberization occurs in the cells of the Protective-layer before leaf-fall, but subsequently the deposition of suberin on the inner face of each cell goes on rapidly, the living elements of the vascular bundle also undergoing this process. The crystal cells in the Protectivelayer become lignified, but no suberin could be detected in their walls.

During the first winter the cork cambium is formed by the regular division of the cells below the Protective-layer, and by its activity gives rise to a few layers of cork. By the end of the second year a thick layer of cork, traversing the vascular bundle and continuous with the stem periderm, has been preserved.

\section{P. VIRGINIANA, Linn. \\ P. COMMUNIS-DULCIS.}

The description of the course of events in P. Cerasus applies generally for $P$. virginiana and $P$. communis-dulcis. There is, however, one point of difference. So far as the examination goes, there is never any ligno- 
suberization of the Protective-layer previous to leaf-fall. In P. Cerasus, as was stated above, lignification of the cells of the Protective-layer almost invariably occurs before the leaf is finally amputated, and in some cases there is a strong tendency towards suberization. But in $P$. virginiana and $P$. communis-dulcis this has not been observed.

\section{CLASS II (b).}

\section{Platanus orientalis, Linn.}

In this well-known plant, the slender cylindrical petiole passes gradually into the swollen base, which externally displays 7-8 prominent ribs corresponding to the leaf-trace bundles beneath. Within the inflated leaf-base there exists a spacious cavity which, while opening to the exterior by a transverse slit on the ventral surface, effectively protects the large axillary bud. Internally, there is the usual distribution of starch granules and crystals (simple and compound) of calcium oxalate, as well as the usual reduction at the leaf-base of the sclerenchyma accompanying the leaf-trace bundles.

The formation of tyloses in the vessels of the leaf-trace usually gives the first indication of approaching leaf-fall. These appear in small numbers in the vessels of the primary wood near the junction of petiole and stem, and are generally accompanied by a small amount of gummy lignin.

As the tyloses increase in number and the gummy lignin in quantity, there is also a slight massing of the protoplasm in the petiolar cells near the leaf-base, which may at the same time acquire a small amount of starch in the form of granules. Slight division then follows, thin walls appearing singly in a varying number of these cells; rarely do all the cells divide, and it is not uncommon to find that no division has occurred at the time of defoliation. Little or no growth takes place in the divided cells, which now begin to undergo ligno-suberization. The cells which first become lignified are usually situated near the epidermis of the basal part of the Protectivelayer, and the process spreads rapidly in the cells of the outer part of the leaf-base and to some extent in the cells of the inner portion. In the same way the cell-walls acquire an inner film of suberin, but though the double process is very apparent in ordinary cases before leaf-fall, it is not until long after that the process is complete, the final stage being reached when the whole of the cells at this level become ligno-suberized and lose their living content

In consequence of the conical shape of the leaf-base, and the added strength given by the regular deposition of the numerous leaf-trace bundles (each of which has its own special patch of sclerenchyma), one might expect to find the provision for separation rather exaggerated. As a matter of fact the Separation-layer in the numerous cases examined was found to be a very transitory affair, consisting of cells in which apparently no preparations had 
been made. It is separated from the Protective-layer by one or two rows of cells, and although its protoplasm is rather conspicuous, little or no starch is present, and except in rare cases no division walls appear. The Separation-layer first becomes well marked near the dorsal surface; its walls begin to swell, the middle lamellae become mucilaginous and finally disappear, and the leaf is thrown off.

During the first winter the cells beneath the Protective-layer become active and give rise to a cork cambium which is continuous with that of the stem periderm. The layer of cork produced before the second season is usually not very thick, and is not continuous across the vascular bundles. Towards the end of the second season a new phellogen arises below the first one, and dipping down towards the cortex crosses the vascular bundles and is only interrupted by the thick patch of sclerenchyma outside each leaftrace.

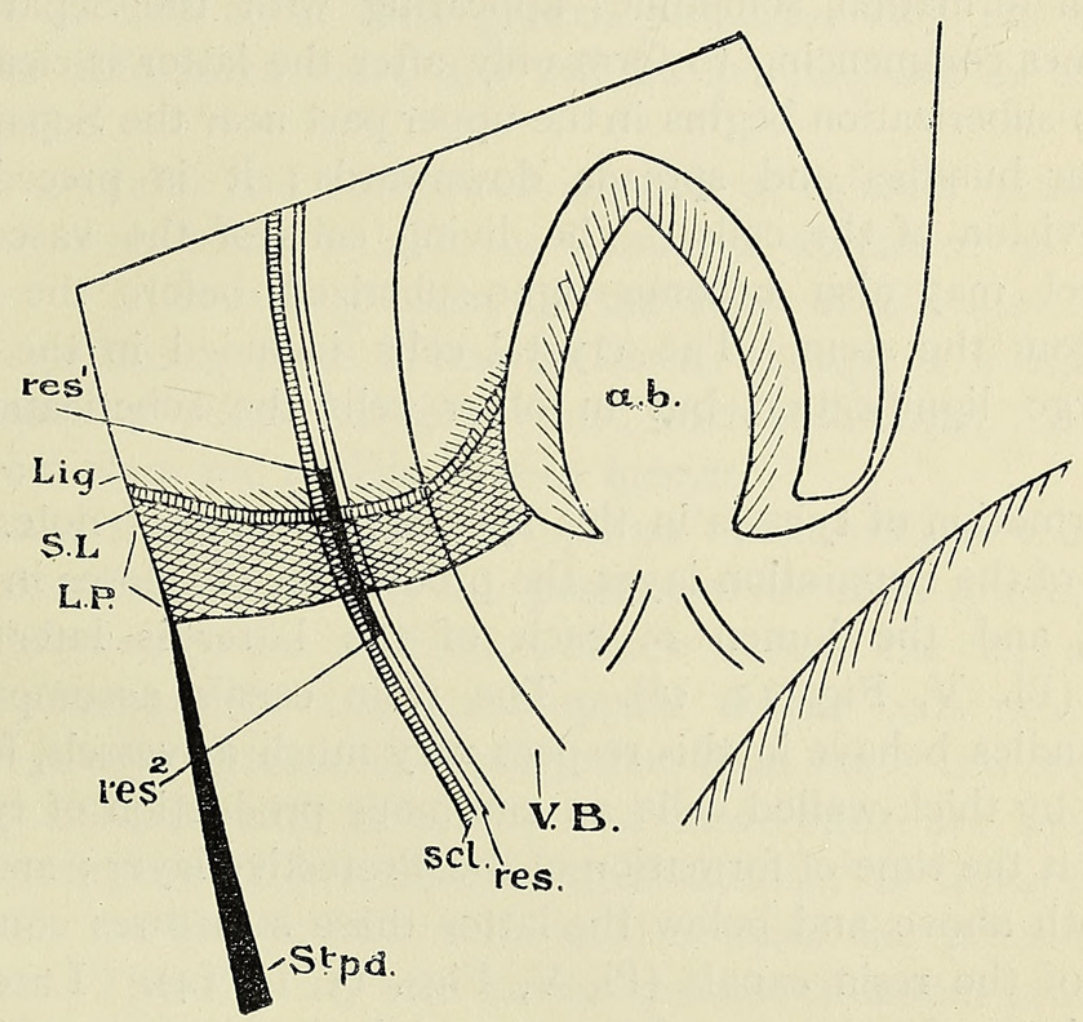

TEXT-FIG. I5. Rhus typhina. Longitudinal section of leaf-base at leaf-fall. res. = resin duct ; res. $^{1}$ and res. ${ }^{2}=$ limits of 'tyloses' in resin duct.

\section{Rhus TYPHINA, Linn.}

This species is rather interesting in the fact that in its leaf-fall processes it appears to combine the characters of $R$. cotinis and $R$. coriaria as described by Tison. The whole plant is very hairy. The stout petiole has a swollen base which encloses the large axillary bud. The distribution of starch and calcium oxalate crystals is as usual, and periderm is usually present before leaf-fall. Numerous resin canals surround the vascular ring 
in the stem, and each is protected by a layer of sclerenchyma. At least one canal (Text-fig. I 5, res.) accompanies each of the three bundles which pass into the leaf, and the sclerenchyma ( $(\mathrm{scl}$.) surrounding it does not diminish to any great extent at the leaf-base.

The Separation-layer (Text-fig. I 5, S.L. and Pl.V, Fig. I I) is formed quite early by division of a layer of cells situated at some distance above the upper extremity of the stem periderm. The protoplasm first becomes conspicuous and starch granules are formed; numerous regular walls appear, usually 2-5 in each cell, and the fully-formed Separation-layer, which often has a thickness of $2-3$ cells, may diminish to one cell at the ventral surface of the petiole.

A conspicuous Lignified-layer ( $L i g$. .) is formed by the lignification of the cells immediately above the Separation-layer. The Protective-layer (Text-fig. I5 and P1. V, Figs. II and I2, L.P.) varies greatly in relative time of formation, sometimes appearing with the Separation-layer, at other times commencing to form only after the latter is clearly marked out. Ligno-suberization begins in the upper part near the Separation-layer and vascular bundles and spreads downwards; it is preceded by the irregular division of the cells. The living cells of the vascular bundle at this level may also become ligno-suberized before the leaf finally separates from the stem. The crystal cells included in the Protectivelayer undergo lignification, but in other cells the suberization is most marked.

The formation of tyloses in this species is worthy of note. With the appearance of the Separation-layer the production of tyloses in the vessels commences, and the lumen of each of the latter is later completely obliterated ( $\mathrm{Pl}$. V, Fig. I 2, $\left.v^{1}\right)$. The resin canals accompanying the vascular bundles behave in this respect very much as vessels, for although surrounded by thick-walled cells an enormous production of tyloses commences about the time of formation of the Protective-layer; and for a little distance both above and below the latter these structures completely fill the cavity of the resin canals (Pl. V, Figs. II, I3, I4). Later these ingrowths undergo the changes of any part of the leaf-base in which they are situated, and in this way help to make more efficient the various modifications connected with leaf-fall.

A very curious phenomenon noticed in connexion with this species is the evident individuality of each leaf. In any twig the leaves in which the leaf-fall processes are most advanced are not, as in most cases, the lowest, but in several instances where two adjacent leaves were examined, the one nearer the apex might be on the point of falling, whilst in the other not a trace of the formation of the Separation-layer would be apparent. Quite analogous with this is the difference in degree of completeness of the leaf-fall processes at the time of leaf-fall, for while in some the elements of 
the Protective-layer are completely ligno-suberized at this time, in others the process is not completed until long after the leaf has fallen.

Separation occurs in the usual way. The primary walls of the Separation-layer become slightly swollen, the middle lamellae become mucilaginous and disappear, leaving the neighbouring cells quite free.

During the first winter divisions in the cells beneath the Protectivelayer result in the formation of a cambium which gives rise to a continuous layer of cork. Later another cambium arises beneath the first one and traversing the vascular bundle adds greatly to the thickness of the layer of cork.

\section{BROUSSONETIA PAPYRIFERA, Linn.}

\section{Ficus CARICA, Linn.}

These two plants are being taken together because in their leaf-fall phenomena, as well as in their general affinities, they are very similar. What slight differences there are will be pointed out in the course of the description.

Starch granules and compound crystals of calcium oxalate have the usual distribution, while laticiferous tissue is abundant in both cortex and petiole. Periderm is present in the stem of Broussonetia previous to any change taking place in the leaf-base, though it is entirely absent from the stem of Ficus for some time after defoliation. Sclerenchyma is absent from stem and petiole in both species.

The usual massing of the protoplasm in the cells of the leaf-basewhich are also distinguished by the possession of starch granules and large nuclei-is followed by the production of new walls in the cells of this active area; and although the first walls appear in the cells near the dorsal surface, the process spreads so rapidly that soon there is a complete layer of dividing cells, in each of which $\mathrm{I}-4$ new walls are produced. As these cells complete their divisions, their activity is transferred to the adjacent cells on the petiolar side, and in these the process of division is continued. The dividing cells always possess abundant protoplasm and starch granules; and the sequence of events is continued until a layer 4-8 cells in thickness have undergone division. The last layer to divide retains its protoplasm, and become the Separation-layer, this statement being especially true of Broussonetia ; in Ficus the Separation-layer may or may not have undergone division. All the new walls are approximately parallel with each other and roughly at right angles to the axis of the petiole.

Almost as soon as the first layer has completed its divisions, lignosuberization commences and spreads in the direction of the Separation-layer. It is, however, very feeble, and its lower limit indefinite, and the chemical change accomplished before leaf-fall is very variable and usually not very 
striking. The crystal cells do not undergo division, and only lignin can be detected in their walls.

The development of tyloses is the important factor in the closure of the vessels at the level of the Protective-layer. At a very early stage they appear in the vessels of the primary, and sometimes in the secondary wood, and later are accompanied by a varying amount of gummy lignin.

As soon as the Separation-layer has become well marked the adjacent petiolar cells, some of which have divided, become highly lignified, and finally lose most of their contents and exhibit great rigidity.

Separation takes place by the disappearance of the middle lamellae of the outer cells of the Separation-layer. In late autumn, after the leaf has fallen, the cortical cells adjacent to the Protective-layer become active and begin to undergo regular division, the result of which, however, is not manifest until the following year, when by their activity a thick layer of cork is added to the Protective-layer. The phellogens of the stem and Protectivelayer soon merge into each other, and the layers of cork subsequently produced are identical in form and reactions.

For closure of laticiferous tubes see description of Morus and Pl. VI, Fig. I7.

\section{MORUs ALBA, Linn., and M. NIGRA, Linn.}

When mature the stout, cylindrical petiole is distinguished from the brown stem by its green colour. Internally, there is little difference between the cells of the stem and those of the petiole, and while starch is present only in the former, compound crystals and much laticiferous tissues are found throughout. None of the 'stone' cells which accompany the vascular tissue in the stem are found to extend into the petiole. A superficial periderm is present in the stem before leaf-fall.

The massing of the protoplasm in the cells of the leaf-base is followed by the appearance of numerous $(2-8$ in each cell) new walls in the latter, running in a direction approximately at right angles to the long axis of the petiole (Pl. VI, Fig. I5, L.P.). Although the mother-cells increase in length they still retain their distinctive outline; and while it may be said that the whole of the cells of this layer usually divide almost simultaneously it must be noted that there is often a distinct tendency for one row to divide at a time, the activity then passing to the next row of cells on the petiolar side. The final result is that a thick layer of divided cells is produced in which the crystal cells and epidermal cells alone have not undergone division.

As soon as the process of division is well advanced, ligno-suberization commences near the upper limit of the Protective-layer, and spreading rapidly in all directions may even extend to the undivided cells of the cortex. The whole of the Protective-layer becomes uniformly suberized, but the lignification is more marked in the cells near the upper limit. The 


$$
\text { Lee.-The Morphology of Leaf-fall. }
$$

last signs of the conspicuous nuclei disappear with the completion, before leaf-fall, of these chemical changes.

Numerous fairly regular divisions which occur in the cells of the petiole adjacent to the Protective-layer result in the formation of a well-marked Separation-layer (S. L.), in which starch is present in considerable quantity. After several divisions have occurred, the primary walls begin to swell, at the same time taking the haematoxylin and ruthenium-red more strongly. Later the middle lamellae between the outer cells become mucilaginous and disappear, and with the subsequent rupture of the vascular tissue the leaf falls to the ground. A Lignified-layer ( $\mathrm{Lig}$.$) is also present.$

Tyloses and gummy lignin appear very early and become very abundant in the vessels of the primary and secondary wood at the level of the Protective-layer. Tison has already described the manner in which the laticiferous elements behave near the region of separation. Latex tubes in these plants are very numerous, and as those of the cortex communicate with their fellows in the petiole, it follows that a considerable number must traverse the Protective-layer. Those parts which are enclosed within the latter do not become divided as do the ordinary cells of the Protective-layer; their walls, however, become lignified and probably suberized, though the latter process is not at all definite. When separation is taking place there can often be observed a direct squeezing out of the latex tube in the region of the Separation-layer, the process finally culminating in the complete rupture of the tube at this point (P1. VI, Fig. 15).

But the most interesting point in connexion with the behaviour of the laticiferous tubes appears to relate to the phenomenon mentioned by Parkin ${ }^{1}$ for other laticiferous plants, i. e. Hevea brasiliensis and Plumiera acutifolia. This author found that if a mature leaf is cut off half-way up the petiole, latex exudes copiously from both cut surfaces; nearer the leaf-base the amputation results in copious exudation of latex from one surface only, that of the petiole, while if the leaf is cut off flush with the surface of the stem, the flow of latex is from the stem only. In the species examined by Parkin the only reason he could discover for such behaviour consisted in the appearance near the leaf-base of a number of crystal cells which seemed to cut off the latex tubes. So far as Parkin could discover there was no formation of walls within the tubes themselves.

Now in M. alba and nigra, as well as in Ficus Carica and Broussonetia papyrifera, just before leaf-fall definite walls are formed in the laticiferous tubes near the leaf-base, though so far it has been impossible to work out the details of their formation. If longitudinal sections are taken of the bases of leaves which have a fully-formed Protective-layer and the latex is dissolved out by any of the ordinary methods, distinct walls will be found traversing the tubes at a varying distance on either side of the Protective-

1 Annals of Botany, vol. xiv, I900, p. 205. 
layer (P1. V and VI, Figs. I5, I6, I7). These walls are invariably very definite ; they give the usual cellulose reactions, and are often curved so that the convex side is towards the Protective-layer. This arrangement, although not invariable, is noteworthy, for it often appears to be connected with the presence of abundant latex on the concave side of the walls and with the degeneration (and therefore lower pressure (?)) of the substance enclosed by the walls.

With regard to the formation of these walls nothing very definite has been observed. As Tison has said, they probably arise very rapidly, and the first stages are therefore difficult to obtain. The same author holds that the coagulation of the latex near the Protective-layer often provides an obstruction, and may possibly aid in the formation of the transverse wall. In the present case a coagulated mass of latex, such as Tison describes as being present on the convex side of the transverse wall, has never been found, though masses of various size have been observed dispersed throughout the tubes; and while it is highly probable that there is some relation between the formation of the transverse wall and the nuclei within the tube in that region, it has as yet been impossible to establish any such connexion.

The condition of the Protective-layer at the time of leaf-fall has already been described. The amputation of the leaf is followed by the extension into the leaf-trace of the process of ligno-suberization and by the formation beneath the Protective-layer of a cambium, which gives rise to a few regular rows of cork cells during the first part of the winter. Without traversing the vascular bundle, this cambium soon becomes continuous with the phellogen of the stem; it is not very vigorous during the first year after leaf-fall, rarely more than $4^{-6} 6$ rows of cells being produced. In the second year a new cork cambium arises just beneath the old one, and in turn gives rise to a layer of cork which completely traverses the vascular bundle.

\section{JUGLANS NIGRA, Linn.}

The course of events is very much as in Morus and other examples of this type. The usual reduction occurs in the vascular and strengthening tissue at the leaf-base. A superficial periderm is present in the stem and often extends a little way up the petiole. Aggregation of the protoplasm in the cells of the leaf-base is followed by irregular division, the new walls appearing, I-3 in each cell. A fairly thick layer is thus produced which has a slightly curved course. Ligno-suberization takes place as usual.

The Separation-layer is formed by the more regular division of a layer of $2-3$ rows of cells adjacent to the Protective-layer. Separation follows as in other examples. A slight Lignified-layer is also present.

Protective-periderm does not arise until about the middle of the first 
winter. The cork is at first small in amount, but the activity of the cambium in the second year produces a thick layer of periderm.

Tyloses are usually very numerous and gummy lignin abundant.

J. REGIA, Linn, and J. RUPESTRIS, Engelm.

So far as these species have been examined, the sequence of events leading to and resulting from defoliation is very similar to what has been briefly described for $\mathcal{F}$. nigra.

\section{Cornus SANGuinea, Linn.}

There is nothing remarkable in the external morphology of the leafbase and adjacent parts in this well-known species. Each leaf-the junction of which with the stem is marked externally by a slight furrow-is supplied with three vascular bundles, which from the base of the petiole upwards are entirely free from sclerenchyma. Starch granules and compound crystals of calcium oxalate are present in the stem until very late in the first year.

Some time previous to leaf-fall, a large area of cells (L.P., Text-fig. I6) extending an appreciable distance up the petiole become distinguished by their greatly increased living and starchy contents, and begin to divide by walls which appear usually singly in each cell. The new walls, which are orientated in all directions, thicken slightly, and the whole area begins to

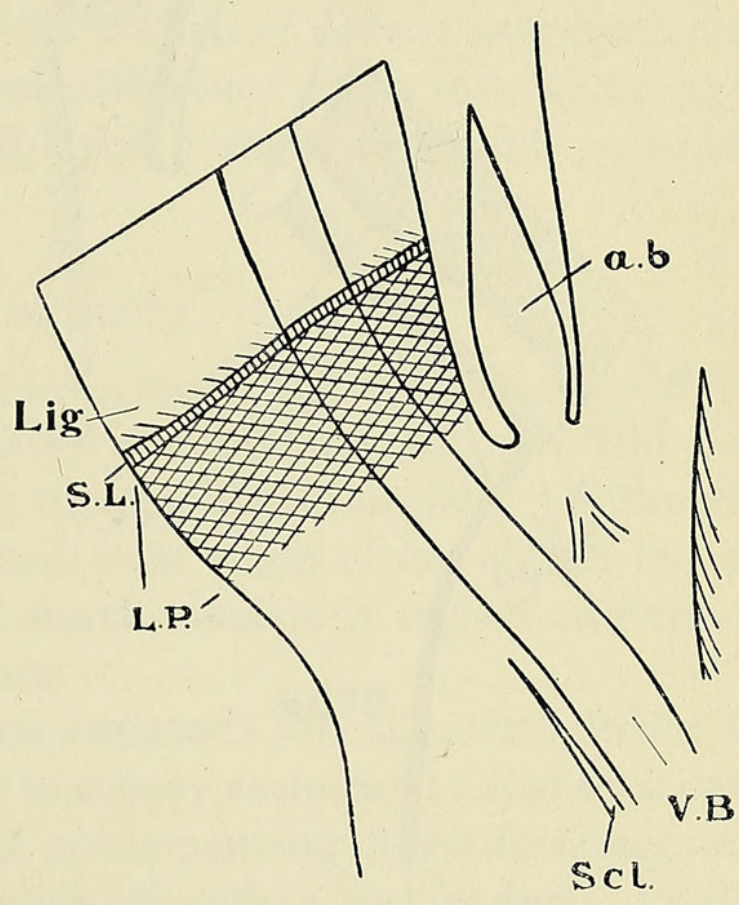

TeXT-FIG. I6. Cormus sanguinea. Longitudinal section of leaf-base at time of leaf-fall. undergo lignification. The latter process is usually very diffuse, and appears first in the upper part of the Protective-layer, from whence it spreads rapidly downwards until the whole of the cell-walls become more or less completely lignified. At the same time there is also a slight degree of suberization, which finally results in the production of an inner film of suberin on each cell-wall. The whole process is not complete until after leaf-fall, varying in this respect to a remarkable degree in the different examples, the progress made in each case being marked by the amount of protoplasm remaining in the cells.

Divisions which lead to the formation of the Separation-layer take place at any early stage-almost as soon as any marked change has occurred in the cells destined to form the Protective-layer-and affect 2-3 rows 
of cells adjacent to the upper margin of the latter (S.L.). These cells are at once distinguished by the presence of dense protoplasm and abundant starch ; the new walls, numbering $2-5$ in each cell, always remain thin, and run in a direction roughly at right angles to the length of the petiole. The mother-cells begin to swell, and though retaining for a long time their cellulosic character, the middle lamellae of the outer cells disappear, leaving the cells on either side perfectly free.

The continuity of the Separation-layer across the leaf-trace bundle is well shown in this example, though other changes which occur in the vascular

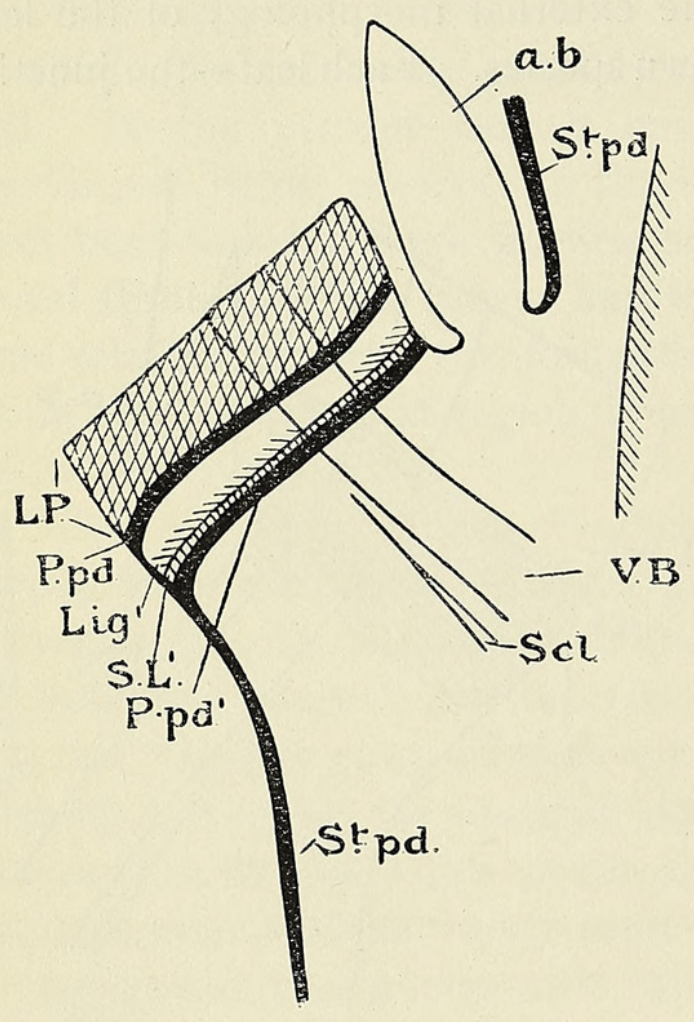

TeXt-FIG. I7. Cornus sanguinea. Longitudinal section of leaf-scar in second spring. elements are not quite so marked as usual. Tyloses are far from numerous in the vessels at the level of the Protective-layer, and gummy lignin, though present, is never abundant. Even after leaf-fall the vascular elements do not become completely closured by these means, but this is accomplished later by the great crushing which takes place when the cells near the surface begin to dry up. A slight Lignified-layer is invariably present above the Separation-layer.

It is not until after the leaf has fallen that there is any formation of periderm cork beneath the Protective-layer, and even then it is very variable. During the first winter divisions which take place beneath the Protective-layer lead to the formation of a cambium, by the activity of which a varying thickness of cork is produced before the second season (Text-fig. I7, $P$.pd.).

In the following spring a curious variation from the ordinary course is seen to occur. Most observers will have noticed that in Cormus sp. and other examples, the resumption of growth of the axillary bud is the signal for the casting off of the adjacent scar tissue ; and it is not very difficult to ascertain the mechanism by means of which this is effected. About this time the cells of a layer situated at some distance below the Protectivelayer become active and give rise to a new Separation-layer in all respects exactly similar to the first. Its action is precisely the same, and results, as was remarked above, in the cutting off of the scar tissue in early spring (Text-fig. I 7, S. L.). Above the secondary Separation-layer is a well- 
marked Lignified-layer, while below it a new periderm is afterwards produced, of which a small proportion is phelloderm ( $L i g$. and $\left.P . p d .{ }^{1}\right)$.

\section{CORnUs MAS, Linn.}

In all the essential stages $C$. Mas is very similar to $C$. sanguinea. It was remarked in the description of the latter species that much variation exists in the degree of completeness attained by the ligno-suberization of the Protective-layer before leaf-fall. This is carried to its extreme in C. Mas, where at the time mentioned no ligno-suberization has occurred. The later modifications and ultimate result are the same as in $C$. sanguinea.

\section{Nyssa sylvatica, Marsh.}

Leaf-fall in this species is very similar to that of Cormus sanguinea, and calls for no special description. A small difference which may be noted is the complete absence of the Lignified-layer, a slight formation of which was remarked in $C$. sanguinea.

\section{Ailanthus glandulosa, Desf.}

The petiole of $A$. glandulosa is very stout and cylindrical, and its swollen base is delimited from the stem by a well-marked furrow; while in a slight hollow on the upper face rests the small axillary bud. Internally the cells of the petiole are distinguished from those of the cortex by the absence from the former of granules of starch, numerous crystal clusters of calcium oxalate occurring in both tissues.

A continuous ring of sclerenchyma surrounds the vascular cylinder in the stem. Five bundles leave the ring to supply each leaf, and as they pass out at different levels the sclerenchyma accompanying them decreases and finally disappears just below the junction of petiole and cortex. In the leaf-base the bundles divide up and later form a continuous ring (with internal groups), which traverses the petiole and which is supplied with an increasing quantity of sclerenchyma situated outside the bast.

In the stem a periderm which arises in the outer layer of the cortex is invariably present before leaf-fall, and in many cases extends well up the petiole.

The Protective-layer is formed by the irregular division of the cells at the base of the petiole, and, compared with the size of the latter, is relatively thin. It appears very early, and curves slightly towards the cortex. After each cell has divided I-3 times the cell-walls become ligno-suberized, and finally lose their contents. The process of ligno-suberization and its results are invariably complete before leaf-fall, the living elements of the leaf-trace being the last to undergo change. Numerous crystal cells are enclosed within the Protective-layer, and without undergoing division they become 
highly lignified. Quite early in the formation of the Protective-layer tyloses appear in the vessels at that level, and in such numbers as to completely close the latter.

The Separation-layer, which appears just before leaf-fall, is formed by the division of 2-3 rows of conspicuous cells situated just above the Protective-layer. These cells possess the usual characteristics and proceed to divide by $\mathbf{I}-2$ walls. The outer cells increase considerably in length,

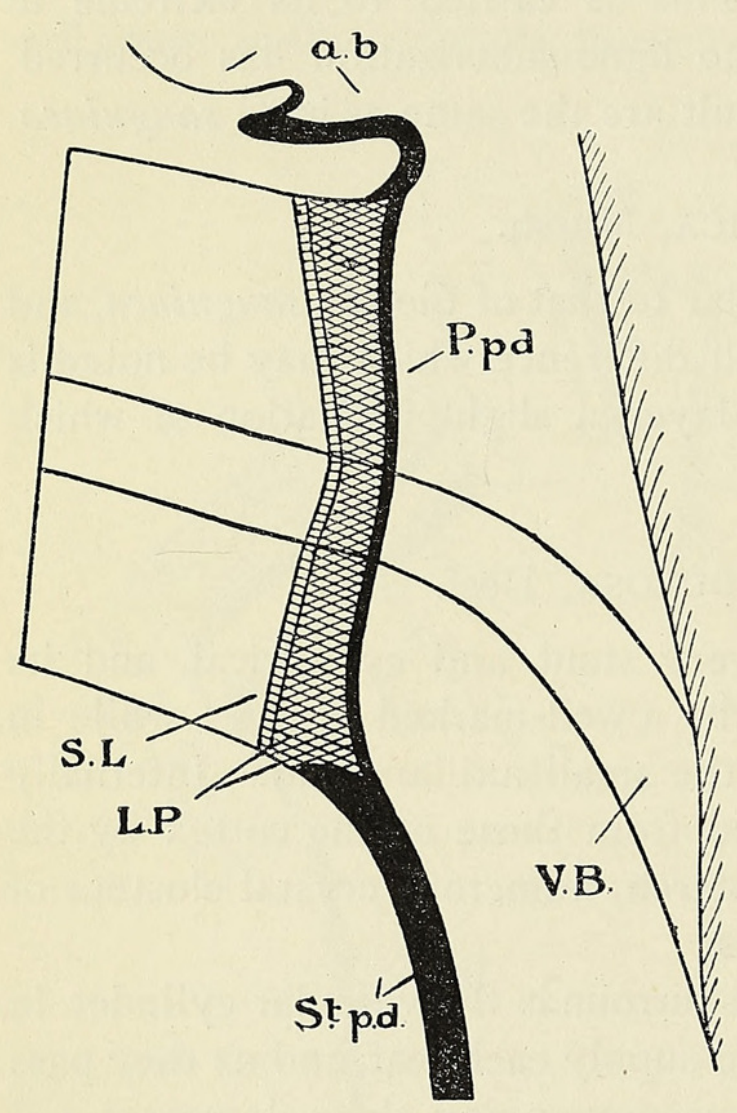

TEXT-FIG. I8. Celastrus articulatus. Longitudinal section of leaf-base just previous to separation.

of unaltered cells. No lignified zone is present above the Separation-layer. nous, and finally the leaf is freed by the solution of the middle lamellae and the rupture of the vascular bundles.

Some time previous to defoliation, the cells below the Protective-layer divide up and form a cambium, which produces 8-io layers of cork in the first year. Almost immediately it traverses the vascular bundle, and the elements above it soon undergo their final change. In the second year a new periderm is produced below the first one, and this, after traversing the vascular bundle, curves gradually to join the stem periderm, enclosing between it and the first Protective-periderm a small area of unaltered cells.

In the scar tissue the cells of the Separation-layer which remain when the leaf has been removed are the last to lose their contents, and for a time they form a conspicuous layer their walls become quite mucilagiCelastrus articulatus, Thunb.

In the stem the ring of bundles is supplied with an internal layer of sclerenchyma, none being present outside the vascular cylinder. A single vascular bundle leaves the ring and enters the petiole, and during its whole course sclerenchyma is entirely absent. In the cortex, the cells of which are generally smaller than those of the petiole, starch granules are invariably present, while crystals of calcium oxalate are only rarely found throughout the plant.

The formation of the Protective-layer (Text-fig. I8, L.P.) takes place in the usual manner of this type. There is a slight increase in the proto- 
plasmic and starchy contents of the cells of the leaf-base, followed by the production of numerous irregular walls. Ligno-suberization soon follows, and gradually a layer 6-12 cells in thickness becomes completely metamorphosed, and forms a well-defined Protective-layer, from which protoplasmic and other contents are entirely absent (Pl. VI, Fig. I8, L.P.).

More regular divisions which now take place on the petiolar side of the Protective-layer lead to the formation of a well-defined Separationlayer (S. L.). Numerous new walls appear in 2-4 rows of cells; the primary walls become mucilaginous, the middle lamellae disappear, and the rupture of the vascular bundle is followed by the fall of the leaf.

Tyloses are introduced into the vessels near the leaf-base at a very early stage, and later there is a copious production of gummy lignin. Before leaf-fall a cambium $(c a$.$) is formed by division of the cells beneath the$ Protective-layer, and soon becomes continuous across the vascular bundle with the phellogen of the stem. In the second year a new cambium arises, and by its activity produces a thick layer of cork.

\section{Phellodendron amurense, Rupr.}

The petiole on the whole is slender and cylindrical, but possesses a swollen base which completely encloses the axillary bud. A brown furrow marks the junction of the petiole with the stem. Numerous cells containing clusters of crystals of calcium oxalate, as well as large cavities containing mucilage, are present throughout the cortex and petiole, while starch granules are abundant only in the cortex. In the stem the pericycle possesses scattered patches of sclerenchyma, some of which accompany the three vascular bundles for a short distance before the latter enter the leaf. At the leaf-base, the sclerenchyma having been entirely lost, the bundles form a semicircle of vascular tissue which traverses the petiole and supplies the lamina. Isolated patches of sclerenchyma occur in both cortex and petiole, and a superficial periderm is present in the stem before leaffall. Throughout the process tyloses are few in number near the Protectivelayer, but the vessels become filled at a later stage with quantities of gummy lignin.

Ligno-suberization takes place in a layer of cells which runs across in a slanting direction from the upper extremity of the stem periderm to the junction of the petiole with the axillary bud. The upper portion of the Protective-layer, having already undergone division by irregular walls, first become ligno-suberized while the lower cells are still dividing, the new walls in the latter being more numerous than in the upper cells. As the divisions are completed, ligno-suberization sets in until finally the whole layer, including the living cells of the vascular bundle, is changed in character. So far as can be seen, the walls surrounding the mucilage cavities and those of the crystal cells undergo complete lignification. 
Before the Protective-layer is completely formed, the cells of a layer above, which is separated from the Protective-layer by I-3 cells, become active, and display abundant protoplasm and numerous starch granules. Numerous division walls appear in this Separation-layer, and the cells increase greatly in size; next their walls begin to swell and become mucilaginous, and finally the complete solution of the middle lamellae paves the way for the full separation of the leaf.

There is no Lignified-layer in this species, but a 'parenchyme sacrifié', consisting of part of the Separation-layer in addition to the cells that intervene between the latter and the Protective-layer, is invariably present. The cells gradually lose their contents, and their walls slowly undergo lignosuberization.

It is not until late winter that a cork cambium is formed beneath the Protective-layer, and even then it does not become very active, only I-2 layers resulting previous to the second season. Later, however, a thick layer of cork cells is produced.

\section{FraXiNuS EXCELSIOR, Linn.}

The stout, roughly cylindrical petiole is delimited from the stem by a well-marked furrow, and encloses within its axil a conspicuous spherical bud. The lignified stereome which accompanies the leaf-trace bundles becomes greatly reduced at the leaf-base, and appearances point to the conclusion that there is also a reduction in the vascular elements in that region. A conspicuous periderm is present in the stem previous to the commencement of the leaf-fall processes.

Tyloses and gummy lignin appear in the vessels near the leaf-base at a very early stage, the latter being deposited in considerable quantity. In a layer eight or more cells in thickness situated near the leaf-base, the protoplasm increases in density, and new walls $(\mathrm{I}-2)$ appear in each cell. Ligno-suberization, which immediately follows, commences near the epidermis or the vascular bundles, and quickly spreads in all directions, a measure of its advance being gained by noting the diminishing density of the protoplasm, which finally disappears when the chemical change is complete.

Divisions ( $\mathrm{I}-4$ in each cell) in the cells of the petiole above the Protective-layer result in the formation of the Separation-layer, which is early distinguished in the usual way, i. e. presence of abundant protoplasm and starch. The swelling of the primary cell-wall and the mucilaginization and disappearance of the middle lamellae are well shown in this example, which altogether furnishes a very easy and diagrammatic type.

After leaf-fall the vascular elements, which have only partly become ligno-suberized, proceed rapidly to complete that process, which is no doubt 


$$
\text { Lee.-The Morphology of Leaf-fall. }
$$

aided by the diffusion from the broken vessels of the abundant gummy lignin which often covers the exposed surface.

Towards the end of the second season the cells adjacent to the Protective-layer divide up to form a cork cambium, which, becoming continuous with the phellogen of the stem, produces a conspicuous layer of regular cork cells towards the scar, as well as a small amount of phellogen towards the cortex.

\section{Catalpa Kaempferi, Sieb.}

The whole sequence of events in this species is quite similar to what has already been described by Tison of $C$. bignonioides. The junction of the stout cylindrical petiole with the stem is marked externally by a dark brown ring, while internally, considerable difference in size exists between the

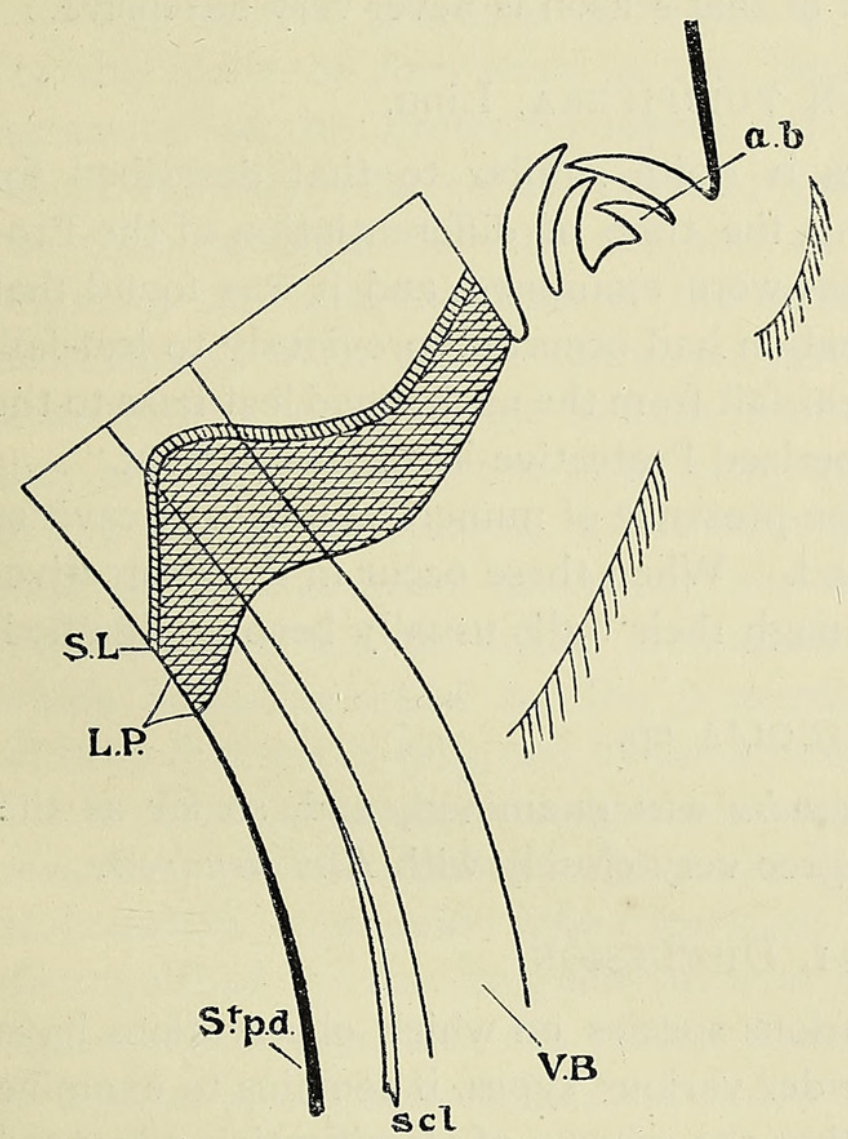

Text-FIG. 19. Catalpa Kaempferi. Longitudinal section of leaf-base just before leaf-fall.

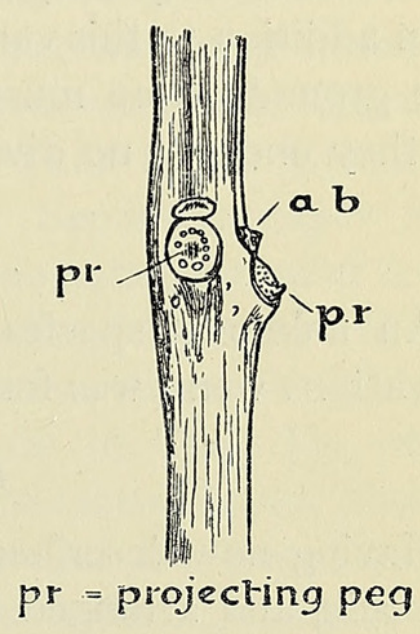

TeXT-FIG. 20. Catalpa Kaempferi. Portion of stem showing leaf-scars with projecting-peg $(p r$.$) .$

parenchymatous cells of these organs. Starch grains are present in the cortex only, but simple (octahedra) and compound crystals of calcium oxalate are abundant throughout. A single group of bundles supplies the leaf, the stereome accompanying which disappears completely at the leafbase. A superficial periderm is present in the stem before leaf-fall.

Aggregation of protoplasm in the cells of the leaf-base, division by walls formed singly in each cell, and lignification followed by suberization 
(from a number of different points) occur in quick succession. The Protective-layer (Text-fig. I9, L.P.) has a peculiar shape, curving upwards from all sides to meet the dorsal leaf-trace, and thus forming a prominent peg which projects above the general surface of the scar (Text-fig. 20, pr.). About this time tyloses and gummy lignin become apparent in the vessels of the vascular bundle near the leaf-base.

The Separation-layer (S.L.), produced by slight division of the cells adjacent to the Protective-layer, possesses the usual characteristics, and separates in the ordinary way by disappearance of the middle lamellae of the outer cells. No Lignified-layer could be detected, but the remains of the Separation-layer form a slight 'parenchyme sacrifié'.

It is usually not until the second season that divisions in the cells beneath the Protective-layer give rise to a cork cambium. In any case the layer of cork produced by the end of that season is never very extensive.

\section{LIRIODENDRON TULIPIFERA, Linn.}

Here the sequence of events is quite similar to that described for Catalpa, the only difference being the time of differentiation of the Protective-layer. Numerous leaf-bases were examined, and it was found that in many little or no ligno-suberization had occurred previously to leaf-fall, all transitions being obtained at leaf-fall from the unchanged leaf-base to the one in which a completely ligno-suberized Protective-layer was present.

In addition to this variation the presence of numerous mucilage cavities in the ground tissue must be noted. When these occur in the Protectivelayer they undergo no division, though their walls usually become lignified.

\section{MAGNOLIA sp.}

An unknown species of Magnolza was examined, and, so far as the observations went, was found to agree very closely with Liriodendron.

\section{General Discussion.}

Having now described the various species on which observations have been made, and arranged them under various types, it remains to examine the available evidence to see whether the scheme of classification advanced is vindicated, and at the same time, if possible, to draw one or two conclusions. The observations here recorded (on species examined by both of us) agree in the main with those of Tison, the variations-usually in time-probably being due to differences of climate and season. The essential modification in connexion with leaf-fall is the occurrence of the Separation-layer, which, therefore, was the first to appear in the course of evolution; other modifications connected with the improvement of the mechanism of the Separationlayer (i.e. the Lignified-layer) and with the protection of the underlying tissues (i.e. the Protective-layer) appeared later, the former in connexion 
with the formation of the Separation-layer, the latter after separation had been effected. In many species the relative times of appearance of the Separation-layer and the Protective-layer are reversed, and in these the provision for protection of the exposed tissue is complete before the leaf is cast off. The form of the protective device, so far as the species at present examined are concerned, appears to have followed three distinct lines :-

I. Ligno-suberization without further modification of existing cells.

2. Ligno-suberization of cells after irregular division has occurred.

3. Ligno-suberization of cells produced by the activity of a regular cambium.

So far as the present research goes, the characters here enumerated, and these alone, are invariable ; and it is on these that the classification of leaf-fall phenomena has been founded.

The system proposed by Tison is very elaborate, and is based on (I) the mode of formation of the Separation-layer; (2) the mode of formation of the Protective-layer; (3) the degree of ligno-suberization which has been effected at leaf-fall ; (4) the amount of cork produced by the cork cambium beneath the scar at the time of defoliation; $(5)$ the origin of the cork cambium of the stem; (6) the exfoliation of scars on dead leaves. Were all the characters just enumerated absolutely invariable, it would still be impossible to form from them classes of co-ordinate value ; they are far too dissimilar to be comparable. Again, over and over again in the above descriptions, it has been pointed out how very variable are most of the characters concerned, and one or two variations taken from Tison's paper will be briefly mentioned here. Thus in his second class, which is distinguished by the possession of a Separation-layer formed without division of cells, and by the absence of ligno-suberization at leaf-fall, Tison places Crataegus monogyna, in which the cells of the Separation-layer sometimes present division walls, and Euonymus europaeus, in which lignosuberization may occur before leaf-fall. Similarly in Class IV, which is distinguished by the irregular division of the Protective-layer, absence of ligno-suberization, \&c., are placed Ficus Carica and Euonymus latifolius, in both of which some ligno-suberization may occur before defoliation. Other examples might also be given to show that some at least of the characters relied on by Tison are of very doubtful value. In addition the results of Löwi's experiments on the effect of different conditions on the Separationlayer show us that the form and extent of the latter depend largely on external conditions; and any one, by repeating von Mohl's experiment in which he placed a healthy branch in a damp chamber, may prove that the formation of the Separation-layer can be induced without the production of a ligno-suberized layer even in species in which, under ordinary conditions, ligno-suberization is complete before leaf-fall. The form of the Separationlayer, the time of ligno-suberization, and the amount of cork produced by 
the cork cambium before leaf-fall are all highly variable, and cannot be relied upon to form the basis of any type.

The species which Tison has classified under Type so appear to be more appropriately referrable to other classes, from which indeed they seem to differ only in the deep-seated nature of the periderm; and the species comprised in his last class (II), while they may differ in other ways, agree in that the scar (or dead leaf) is usually thrown off some time during the second year. In the present work the last-named peculiarity has not been regarded as of sufficient weight to justify the erection of a type. This is because the morphological distinction is not regarded as equal in value to the other characters selected, and also because the class as at present constituted affords an easy transition to the ordinary type in which the leaf-scar is exfoliated by formation of periderm. If the class were limited to those cases in which the dead leaves remain on the tree during the winter, the case for a separate class would be much stronger. But it is not so limited, and therefore the conclusion is arrived at that it is better to trust to the morphological distinctions which depend on the cells forming the Protectivelayer than to rely on the time of exfoliation of the scar.

A consideration of the facts, and especially of the experiments and observations already alluded to, which tend to show that the actual stage which the leaf-fall processes may have reached at the time of defoliation is largely influenced by external conditions, leads to the conclusion that any scheme for the classification of leaf-fall phenomena must be based, not on the features presented at any given time, but rather on the structures which are the ultimate result of leaf-fall. On these lines the simplest and perhaps the most logical scheme appears to be the one now advanced, in which the first class consists of species in which the Protective-layer is formed by the ligno-suberization of cells which have not previously undergone division; the second, of species in which division precedes ligno-suberization; while the third class comprises species in which the Protective-layer is produced by the activity of a regular cambium, and is therefore quite secondary in origin.

In the first two classes there is a gradual transition from species in which the Protective-layer is entirely unchanged at the time of leaf-fall to others in which ligno-suberization is complete at that time; while in the third class, of which only two examples have been described, the Protectivelayer is fully formed at the time of defoliation.

The fall of leaflets in compound leaves has not yet been extensively studied, but from various observations which have been made the rule may be laid down that the leaf-fall structures in leaflets are of the same type as those which occur at the base of the parent leaf, but that they are usually much simpler. A Separation-layer is invariably present, a Lignified-layer may be produced, and the Protective-layer may or may not be well marked, but ligno-suberization is seldom well advanced at leaf-fall. 


$$
\text { Lee.-The Morphology of Leaf-fall. }
$$

A phenomenon which has been touched on briefly in the separate descriptions is the retention through the winter of dead leaves which are cast off in the following spring. Examples of species which do this are far from rare. In some cases, e. g. species of Quercus, Carpinus Betulus, \&c., only a certain proportion of the leaves are retained through the winter, while in others, such as coppiced beech, the whole of the leaves remain on the tree until the following spring.

Although it is impossible to resist the conclusion that this phenomenon depends in some way on the decreased vitality of the plant, no adequate explanation can at present be suggested, and a full discussion of the phenomenon will be left for a future paper.

It was at first thought that it might be found possible to show some connexion between the degree of evolution of the plant and the type of leaf-fall structure; but no such relation has been traced. A cursory examination of the list of species described shows that the individual classes (especially I and II) comprise plants derived indiscriminately from all the families of Dicotyledons. One advantage of the system of classification here proposed is that all species of the same genus so far examined fall naturally into the same class, and in this respect it appears to present some advantage over the more elaborate system proposed by Tison, where different species of the same genus may have to be referred to quite separate groups.

\section{SUMMARY.}

In Dicotyledons the essential modification at the leaf-base in connexion with leaf-fall is the formation of a Separation-layer which is produced from existing cells with or without division.

The leaf separates from the stem by the disappearance of the middle lamellae of the cells of the Separation-layer and the subsequent rupture of the sieve tubes and vessels of the leaf-trace at that level.

A Lignified-layer may or may not be present, but a Protective-layer is invariably produced either before or after leaf-fall.

The mode of formation of the Protective-layer is ( $\mathrm{I}$ ) by lignosuberization of the cells of the leaf-base with or without irregular division ; (2) by ligno-suberization of cells produced by the continued division of a regular cambium.

The following species have been examined :-

\section{Class $I$.}

(a) Castanea sativa, Mill.

Hibiscus syriacus, Linn.

Quercus palustris, Muench.

Ligustrum vulgare, Linn.
Celtis occidentalis, Linn.

Pyrus floribunda, Nichols.

Ceanothus Gloire-de-Versailles (Garden origin). 
Acer pseudo-platanus, Limn.

(b) Ribes sanguineum, Pursh.

Ribes nigrum, Linn.

Diospyrus virginiana, Linn.

Halesia tetraptera, Linn.

Forsythia Fortunei, Hort.

$$
\text { (=F. suspensa, } V a h l) \text {. }
$$

Class II.

(a) Tilia europaea, Linn.

Corylus Colurna, Linn.

Cercis Siliquastrum, Linn.

Carpinus Betulus, Linn.

Prunus Cerasus, Linn.

$$
\text { " virginiana, } \operatorname{Linn} \text {. }
$$

" communis-dulcis.

(b) Betula verrucosa, $E h r$.

Platanus orientalis, Linn.

Rhus typhina, Linn.

Broussonetia papyrifera, Vent.

Ficus Carica, Linn.

Morus alba, Linn.
Baccharis halimifolia, Limn. Gleditschia triacanthos, Linn. Robinia Pseudacacia, Linn.

Clerodendron trichotomum, Thunb.
Morus nigra, Linn.

Juglans nigra, Linn. "regia, Linn.

" rupestris, Engelm.

Cornus sanguinea, Linn.

, Mas, Linn.

Nyssa sylvatica, Marsh.

Ailanthus glandulosa, Desf.

Celastrus articulatus, Thunb.

Phellodendron a murense, $R u p r$.

Fraxinus excelsior, Linn.

Catalpa Kaempferi, Sieb.

Liriodendron tulipifera, Linn.

\section{Class III.}

Salix Caprea, Linn.

Populus balsamifera, Linn.

The protection of the tissues of the stem underlying the scar is aided by the production at a later date of a layer of cork cells which subsequently becomes continuous with the periderm of the stem.

In many species the persistent leaf or leaf-scar is thrown off during the second year.

The above investigation was commenced at the suggestion of Professor J. B. Farmer, F.R.S., to whom the author is sincerely grateful for constant advice and encouragement during the progress of the research.

\section{APPENDIX.}

It has been thought better to give a separate description of the methods employed in this research. The material was collected in July, August, September, October, and November, chiefly in the year 1909, and was preserved in 70 per cent. alcohol. Both longitudinal and transverse sections of the leaf-base were taken, chiefly by hand but also with the microtome, and these were stained with several of the common double stains. For the 
detection of mucilage the ordinary methods were adopted, and for cutin the usual tests were confirmed by treatment with a fresh solution of chlorophyll, when a bright green colour was obtained.

To demonstrate the production of lignin and suberin in the Protectivelayer and elsewhere, separate tests were employed, i.e. for lignin, phloroglucin, aniline sulphate, \&c.; while for suberin, tincture of alkanna and Schultze's macerating fluid were most successful. In favourably stained preparations it is easy to demonstrate the localization of the suberin as an inner film on the lignified middle lamella, but this is better shown by employing the separate tests on consecutive sections. Two other methods are (I) to dissolve away the lignin base by boiling in eau de Javelle, and then to apply the suberin tests; and (2) to dissolve the film of suberin by boiling in macerating fluid, and after careful washing to apply the tests for lignin.

\section{BIBLIOGRAPHY.}

BäSECKE, P. : Beiträge zur Kenntnis der physiologischen Scheiden der Filicinen. I 908.

BretFeld, F. voN : Über Vernarbung und Blattfall. Pringsheim's Jahrbiicher, Bd. xii, 1879-8I, p. 123.

de Candolle, A. P. : Organographie végétale. Paris, 1827 , t. i, p. 123.

Du Hamel, H. L. : Physique des arbres. Paris, I758, t. i, p. 129.

Du Petit-Thouars : Histoire d'un morceau de bois. Paris, I8I 5 , p. 136.

Fouilloy, E. : Sur la chute des feuilles de certaines monocotylédones. Revue générale de Botanique, t. xi, 1899 , p. 306 .

LiNk, H. : Kritische Bemerkungen und Zusätze zu Karl Sprengel's Werk, \&c. Halle, I 8 I 2, p. $5^{\text {I. }}$

LöwI, E. : Über eine merkwürdige anatomische Veränderung in der Trennungschicht bei der Ablösung der Blätter. Österr. bot. Zeitschr. x, 1906, p. 381 .

MoHL, H. von : Über den Vernarbungsprocess, \&c. Bot. Zeit., 1849.

: Über die anatomischen Veränderungen des Blattgelenkes, \&c. pp. I-9.

Murray, J. : Opuscula I. Gottingae, I 765 , p. I 38.

Mustel: Traité théorétique et pratique de la végétation. Paris, 1781, t. i, p. Iog.

Parkin, J.: On Some Points in the Histology of Monocotyledons. Annals of Botany, vol. xii, I 898 , p. I5 I.

: Latex and its Functions. Annals of Botany, vol. xiv, I900, p. 205.

Schacht, H. : Lehrbuch der Anatomie und Physiologie der Gewächse. Berlin, 1859, t. ii, p. I36.

Schultz, K. : Die Natur der lebendigen Pflanze. Berlin, 1823, t. i, p. I 28.

Tison, A. : Recherches sur la chute des feuilles chez les Dicotylédones. Mémoires de la Société Linnéene de Normandie, 1900.

Tréviranus, C.: Physiologie der Gewächse. Bonn, i835-8, t. i, p. 435, t. ii, p. 216.

Van Tieghem, P., and Guignard, L. : Observations sur le mécanisme de la chute des feuilles. Bull. de la Soc. bot. de France, t. xxix, I882, p. 3 I 2.

Vaucher : Mémoires de la Soc. de Phys. et d'Hist. nat. de Genève, t. i, I82I, p. 120.

VROLICK, G. : Dissert. de defoliatione vegetabilium. 1796.

Woodhead, T. W.: Ecology of Woodland Plants in the Neighbourhood of Huddersfield. Journal of the Linnean Society, vol. xxxvii, p. 343 . 


\title{
EXPLANATION OF FIGURES IN PLATES IV-VI.
}

\author{
Illustrating Mr. Lee's paper on Leaf-fall.
}

The lettering applies also to Text-figures I-20.
a.b. = axillary bud.
c.c. $=$ crystal cells.
c. $\quad=$ parenchymatous cells dividing to form Protective-cambium.
ca. $\quad=$ Protective-cambium.
cut. $=$ cuticle.
e.s. $\quad=$ exposed surface of scar.
$e p$. $\quad=$ epidermis.
g. $\quad=$ ground tissue of leaf-base which later will form the Protective-layer.
Lig. = Lignified-layer.
L. $P .=$ ligno-suberized Protective-layer.
$P . p d .=$ first-formed Protective-periderm.
$P \cdot p d .^{1}=$ Protective-periderm formed in sub- sequent years.
p. $=$ cells of petiole.
ph. = phelloderm of Protective-periderm.
p.s. = cells which for a time retain their cellulose character.
$r t . \quad=$ cortical cells.
scl. = sclerenchyma accompanying leaf-trace.
S. $L . \quad=$ Separation-layer.
st..$p d$. . = periderm of stem.
ty. $\quad=$ tyloses.
$t y^{1}$. = tyloses dividing to form Protective- cambium.
u. $L . P .=$ Protective-layer, not yet ligno- suberized.
v. $\quad=$ vessels containing tyloses.
$V . B .=$ leaf-trace.

Fig. I. Castanea sativa. Longitudinal section of portion of leaf-base showing swelling of cell-walls of Separation-layer (S. L.) previous to separation.

Fig. 2. Castanea sativa. Part of longitudinal section of scar showing formation of Protectivecambium.

Fig. 3. Ribes sanguineum. Part of longitudinal section of leaf-base just previous to leaf-fall.

Fig. 4. Tilia europaea. Longitudinal section of periderm beneath old scar, showing wellformed phelloderm $(p h$.

Fig. 5. Betula verrucosa. Part of longitudinal section of leaf-base just before leaf-fall.

Fig. 6. Salix Caprea. Part of longitudinal section of leaf-base at time of leaf-fall.

Fig. 7. Salix Caprea. Part of longitudinal section of first-year scar showing internal cuticle $\left(\right.$ cut $\left.^{1}{ }^{1}\right)$. gum $=$ deposition of gummy lignin on surface of scar.

Fig. 8. Celtis occidentalis. Part of Protective-periderm in longitudinal section. co. $=$ cork.

Fig. 9. Celtis occidentalis. Isolated lignified crystal cells from Protective-layer. crys. $=$ crystal of calcium oxalate. $f .=$ film of lignin round crystal.

Fig. Io. Halesia tetrapiera. Part of longitudinal section of leaf-base just previous to leaf-fall.

Fig. II. Rhus typhina. Portion of longitudinal section of leaf-base showing the continuation of the Separation-layer (S. L.) by division of 'tyloses' within the resin duct. $t y^{1}$. = 'tyloses' becoming ligno-suberized. $t y^{2} .=$ 'tyloses' dividing to form Separation layer. wa. $=$ wall of resin duct.

Fig. 12. Rhus typhina. Part of longitudinal section of leaf-scar showing origin of Protectivecambium (ca.) by division of cells, inclnding tyloses. $v^{1} .=$ vessels which have become ruptured in consequence of growth and division of tyloses.

Fig. I 3. Rhus typhina. Transverse section of resin duct. tyl. = 'tyloses' in resin duct.

Fig. 14. Rhus typhina. Longitudinal section of resin duct.

Fig. I5. Morus alba. Part of longitudinal section of leaf-base showing latex-tube traversing the Protective-layer $(L . P.) . \quad w a .=$ wall in latex tube above Protective-layer.

Fig. 16. Morus alba. Latex tubes with walls (wa.). Arrows show position of Protective-layer.

Fig. 17. Fïcus Carica. Latex tubes. a.b. and $a^{1} b^{1}$ show position of Protective-layer.

Fig. 18. Celastrus articulatus. Part of longitudinal section of leaf-base. 
Atruats of Botany
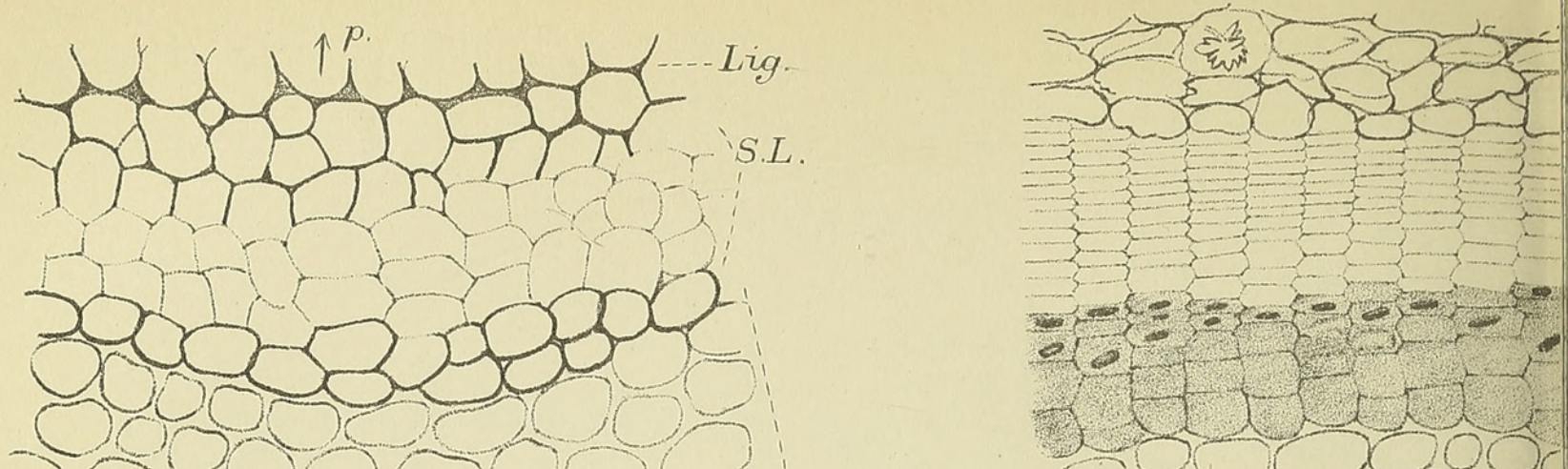

L.P.
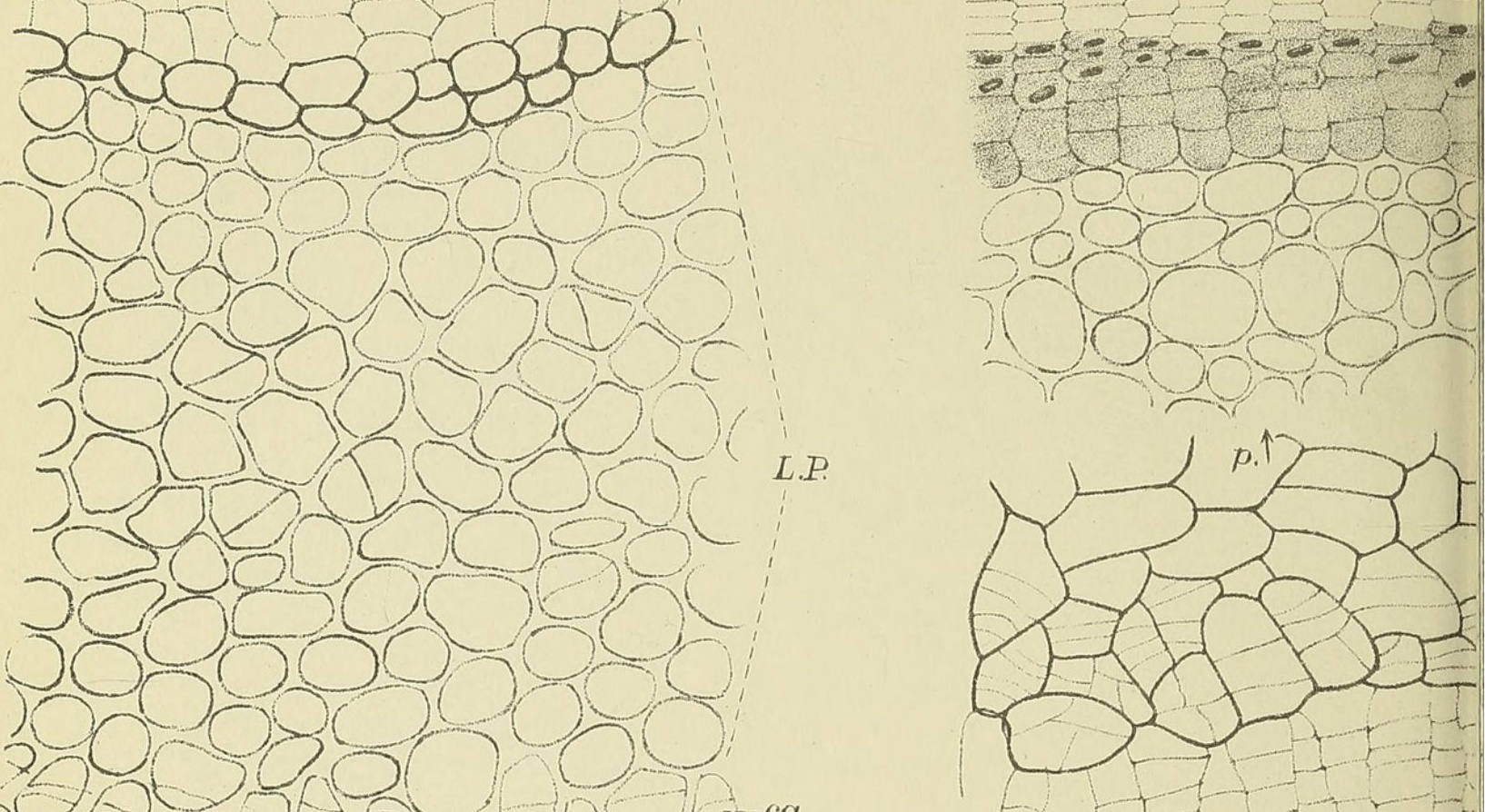

$1600-1-c a$
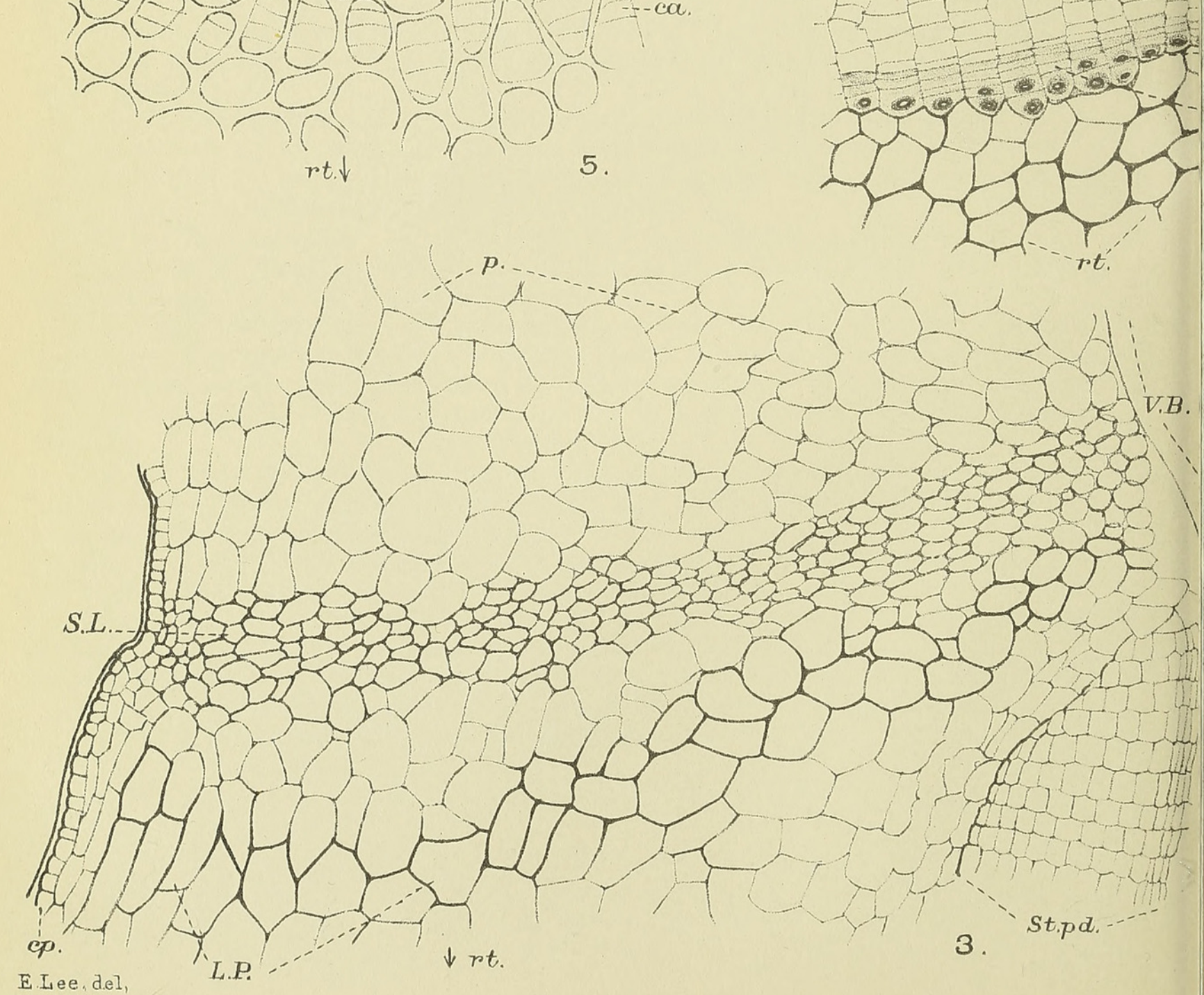

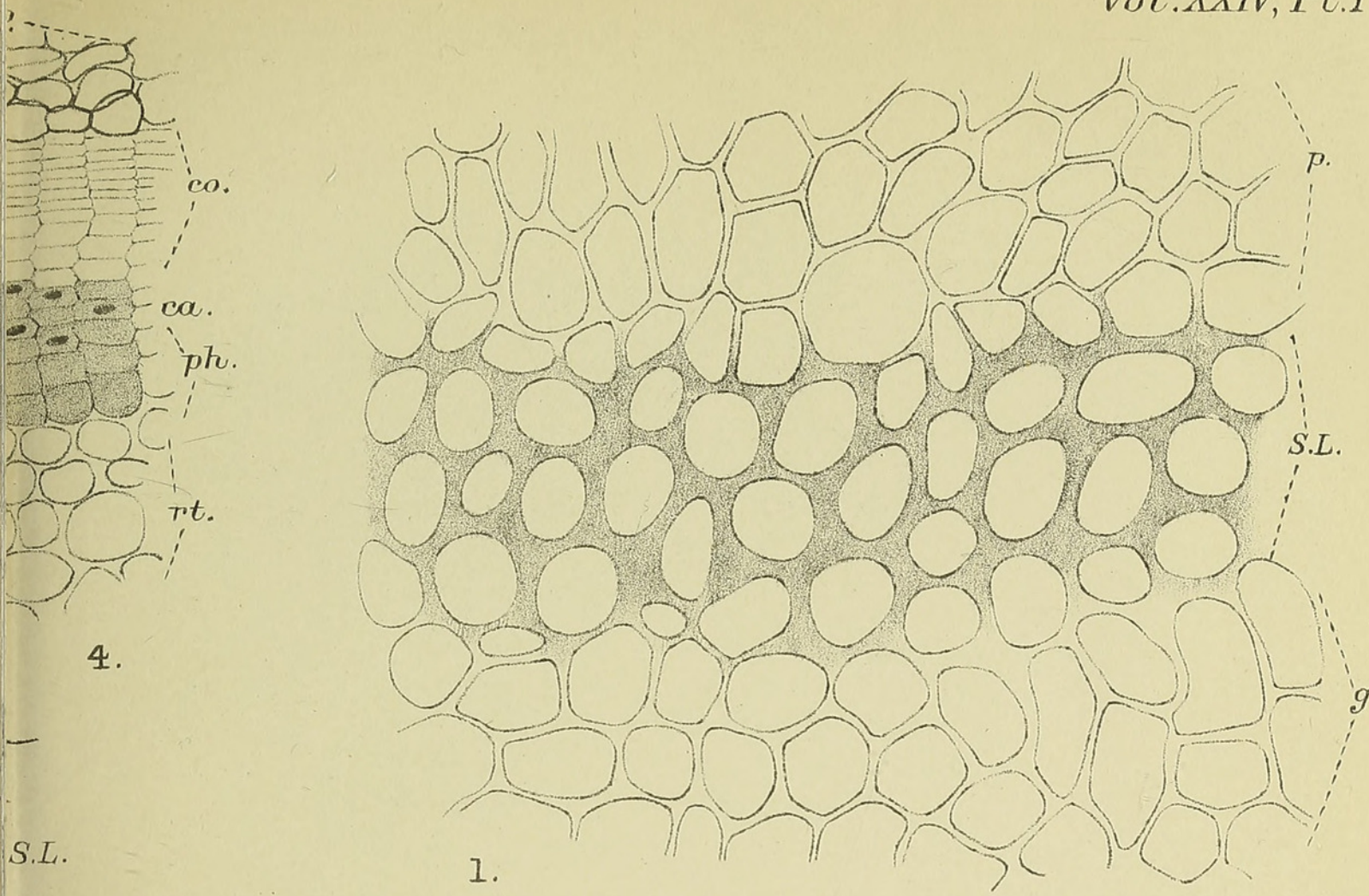

L.P.

4.

S.L.

rt.

phe.

e.s

$\sum_{i \infty}^{p h}$

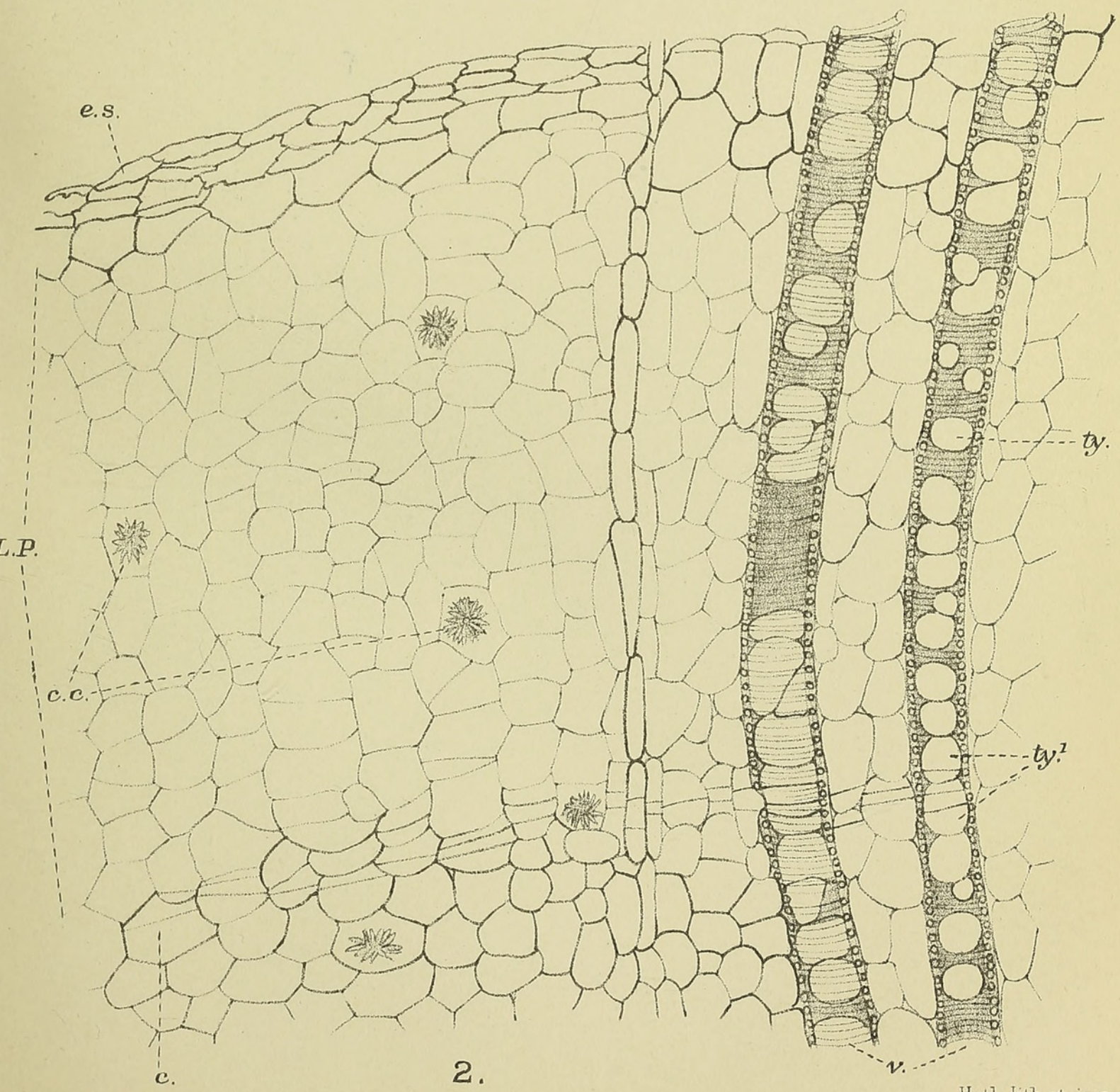


Atrnals of Botany

Fot 503033030 rex 00000 300

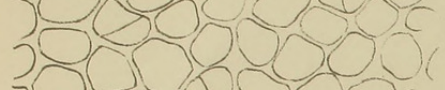
300 300 300000 20600 160 - 0 - A $\overbrace{\substack{r t \downarrow \\ 5 .}}$

,
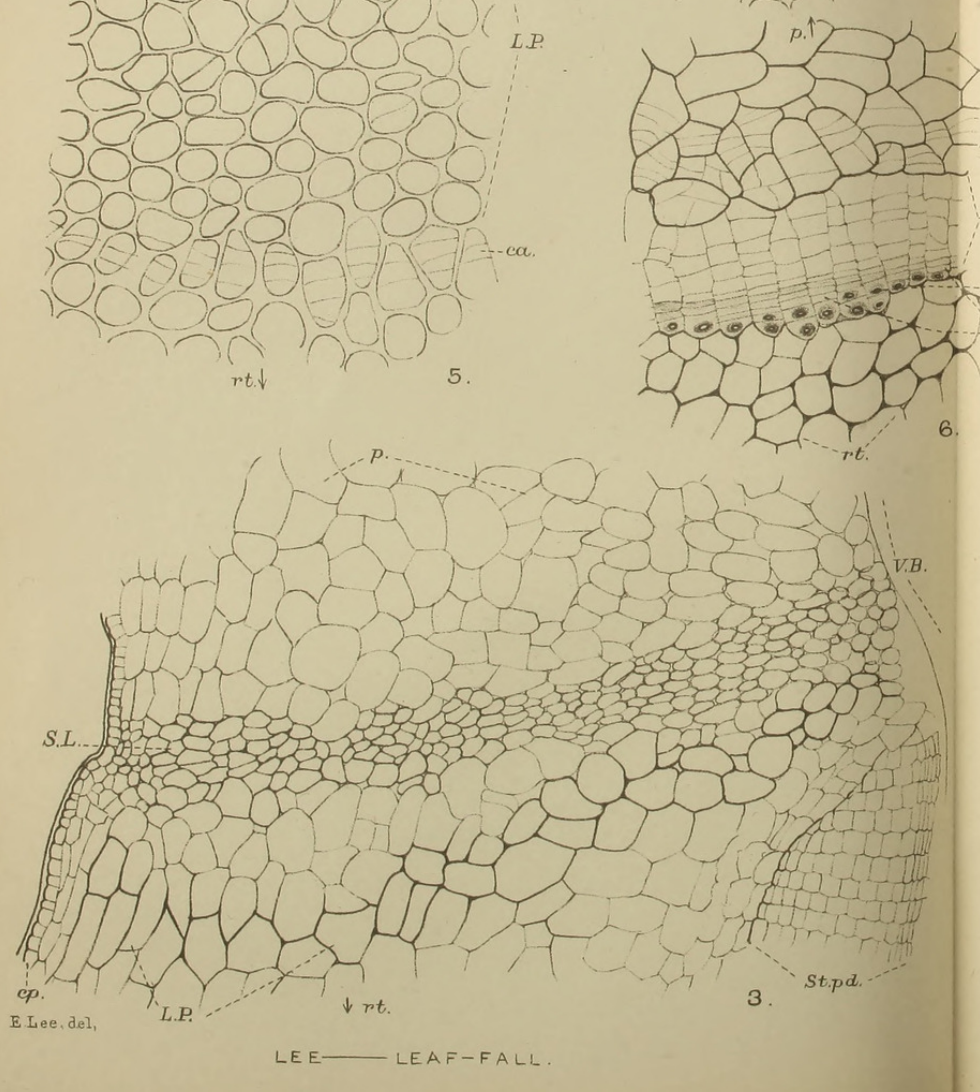

.
Vol.XXIV, Pl.IV.

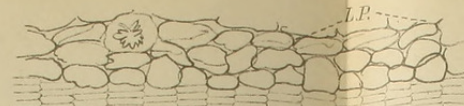

$\Rightarrow 3$ t

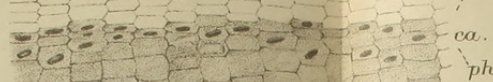

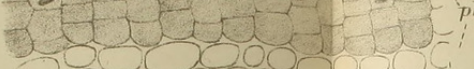

300000000

int.

10000000

4.

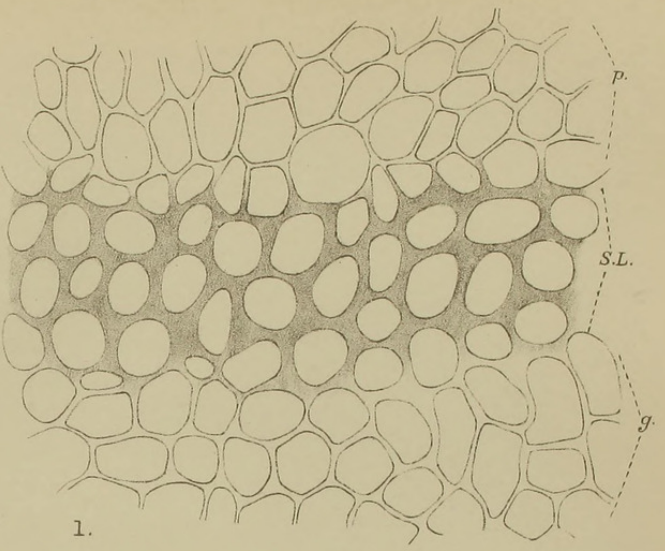

(2)

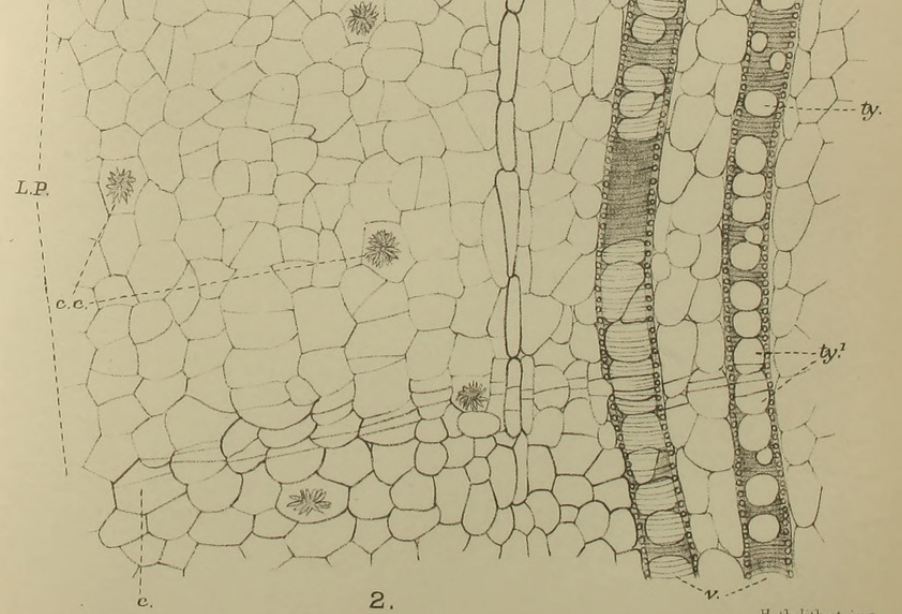


Annals of Botany

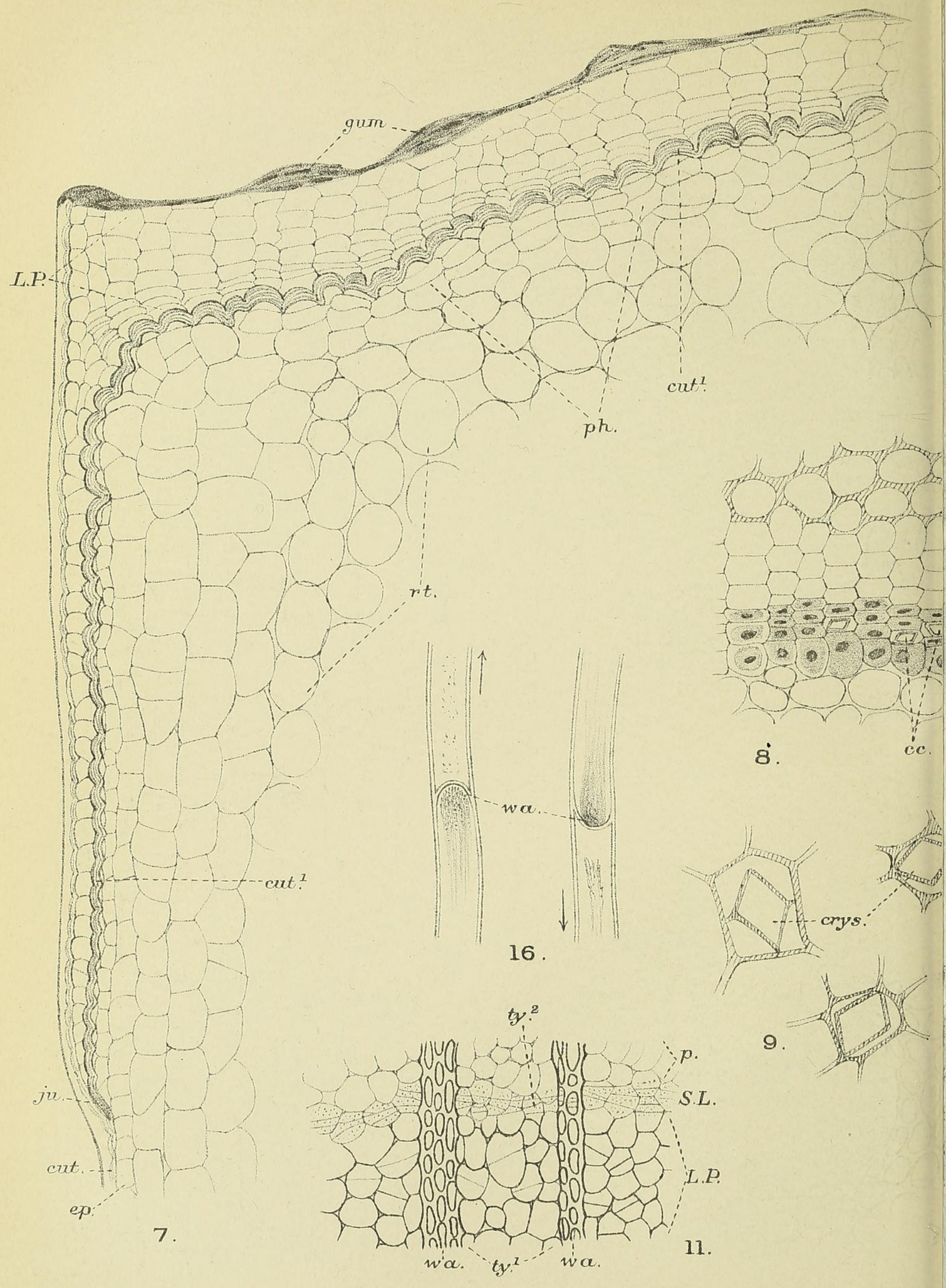

EL Lee, del. 

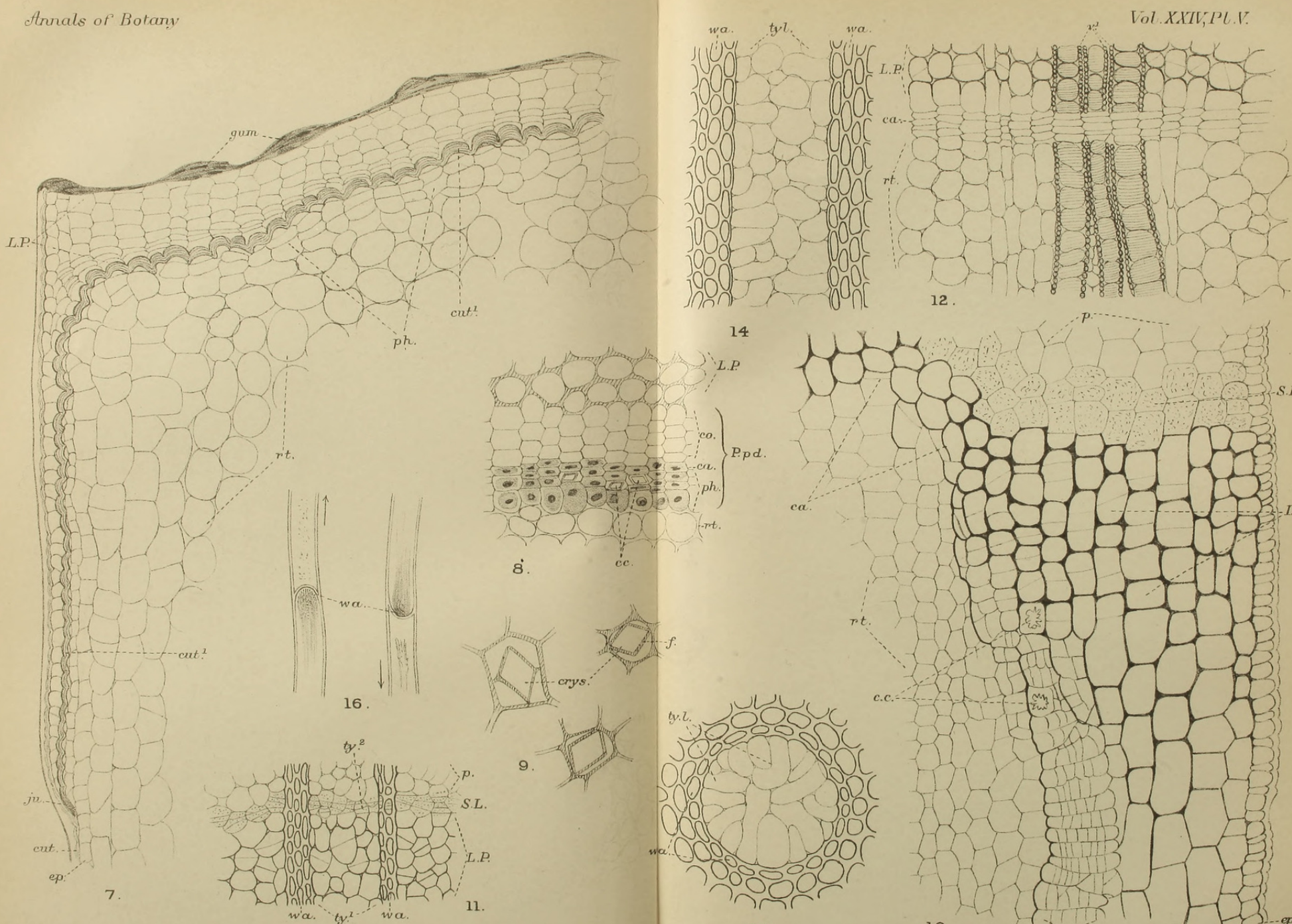

LEE- LEAF-faLL.

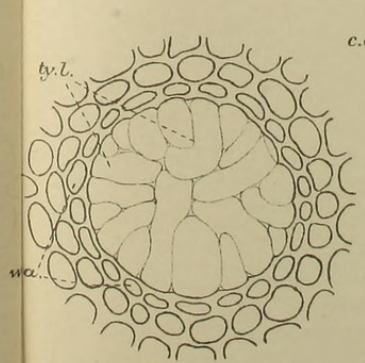

13.

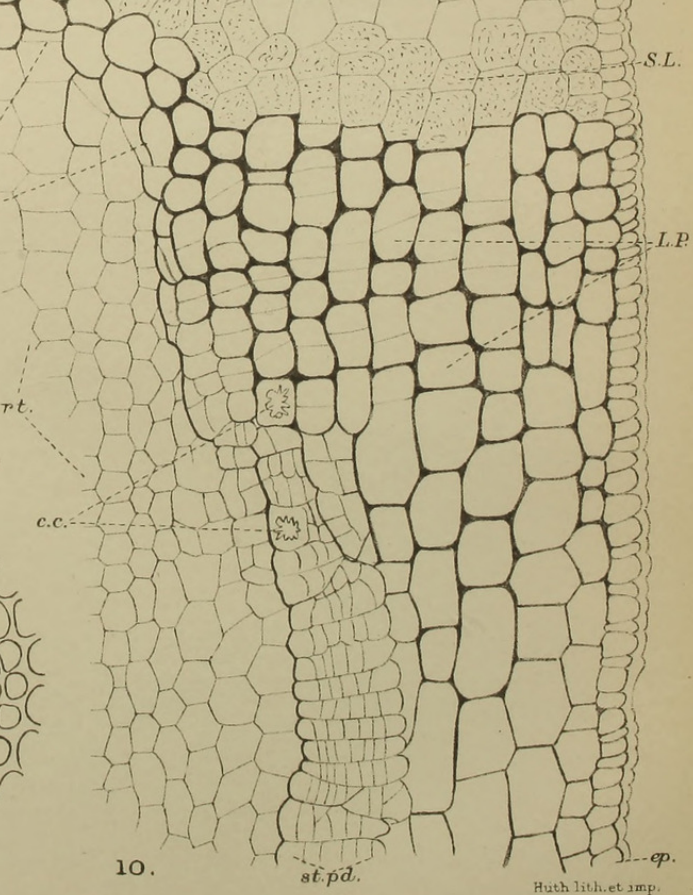


Annals of Botany

Vol.XXIV.PL.VI.
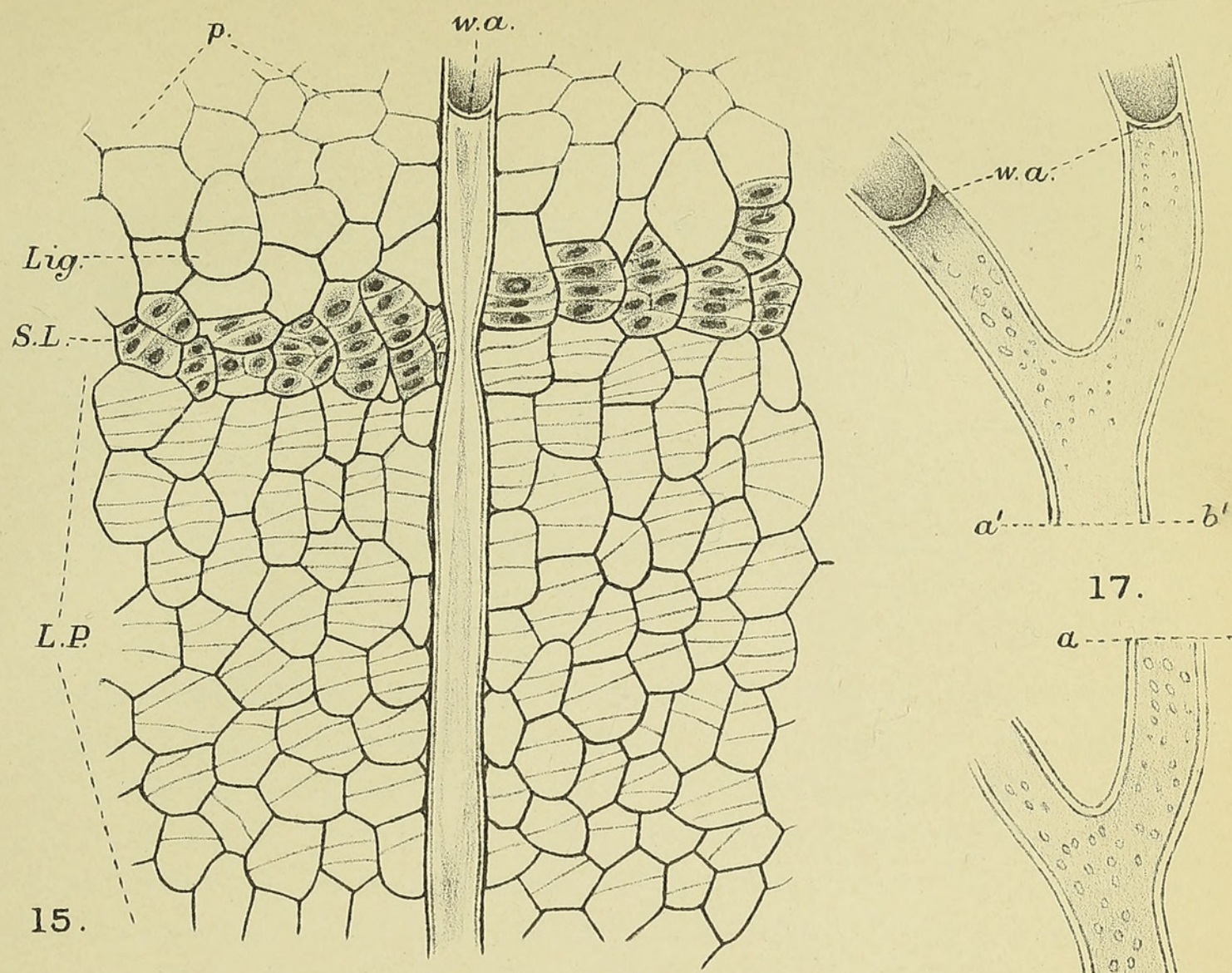

17.
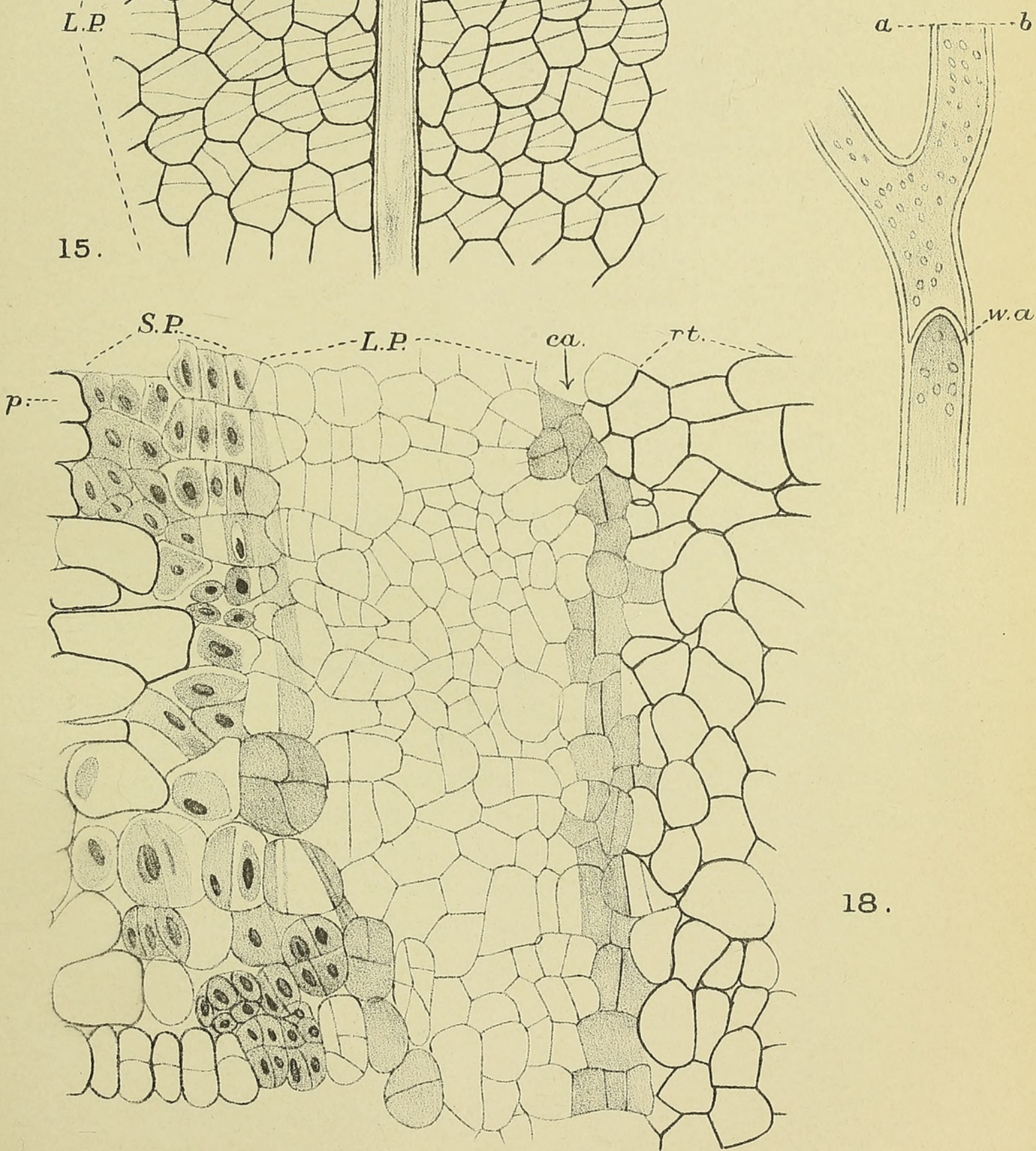

18.

E.Lee, del 


\section{$2 \mathrm{BHL}$ Biodiversity Heritage Library}

Lee, E. 1911. "The morphology of leaf-fall." Annals of botany 25, 51-106. https://doi.org/10.1093/oxfordjournals.aob.a089324.

View This Item Online: https://www.biodiversitylibrary.org/item/236971

DOI: https://doi.org/10.1093/oxfordjournals.aob.a089324

Permalink: https://www.biodiversitylibrary.org/partpdf/319818

\section{Holding Institution}

Smithsonian Libraries

\section{Sponsored by}

Biodiversity Heritage Library

\section{Copyright \& Reuse}

Copyright Status: Not in copyright. The BHL knows of no copyright restrictions on this item.

This document was created from content at the Biodiversity Heritage Library, the world's largest open access digital library for biodiversity literature and archives. Visit BHL at https://www.biodiversitylibrary.org. 